\title{
A retrospective assessment of parental attitudes in alcohol dependent and non-dependent groups
}

\author{
Retrospektywna ocena postaw rodziców w grupie osób uzależnionych \\ i nieuzależnionych od alkoholu
}

\author{
Faculty of Clinical Psychology, Department of Psychology, Kazimierz Wielki University, Bydgoszzz, Poland \\ Correspondence: Ewa Wojtynkiewicz, Department of Psychology, Kazimierz Wielki University, Staffa 1, 85-867 Bydgoszzz, Poland, tel.: +4852 97084 02, e-mail: ewa.wojtynkiewicz@gmail.com
}

Katedra Psychologii Klinicznej, Wydział Psychologii, Uniwersytet Kazimierza Wielkiego w Bydgoszczy, Bydgoszzz, Polska

Adres do korespondencji: Ewa Wojtynkiewizz, Wydział Psychologii UKW, ul. Staffa 1, 85-867 Bydgoszzz, tel.: +4852370 84 02, e-mail: ewa.wojtynkiewicz@gmail.com

\begin{abstract}
Aim: The aim of the studies was to verify whether an alcohol-dependent group differs in terms of retrospectively assessed parental attitudes from a non-dependent group (study 1$)$ as well as whether there are differences between individuals with alcohol dependence having or not having an addicted parent in terms of the retrospectively assessed parental attitudes (study 2). Materials and methods: 121 individuals with alcohol dependence and 121 people with no dependence took part in study 1 (in both groups there were 37 women and 84 men). 221 individuals with alcohol dependence (55 women and 166 men) participated in study 2. Mieczysław Plopa's Questionnaire of Retrospective Assessment of Parental Attitudes (KPR-Roc) and Alcohol Use Disorder Identification Test (AUDIT) were used in the studies. Results: The outcome of study 1 proved that the individuals with alcohol dependence score higher in comparison with those non-dependent in terms of variables Mother Protectiveness, Father Demanding and Father Inconsequence and score lower for variables Father Acceptance/Rejection and Father Autonomy. The results of study 2 show that alcohol-dependent women with a family history of alcohol addiction tended to score lower for variables Mother Acceptance/Rejection, Father Acceptance/Rejection, Father Autonomy and Father Protectiveness in comparison with the non-dependent women with no family history of alcohol addiction. Whereas men addicted to alcohol with a family history of alcohol addiction score higher for the variable Father Acceptance/Rejection and higher concerning variables Father Demanding and Father Inconsequence in comparison with the addicted male group with no family history of alcohol addiction. Conclusion: Alcohol-dependent individuals have a tendency to assess more adversely the father's attitude in comparison with the non-dependent group. Having an alcohol-dependent parent among individuals with alcohol dependence differentiates mainly the retrospective assessment of the father.
\end{abstract}

Keywords: parental attitudes, mother's parental attitude, father's parental attitude, alcohol dependency

Cel: Celem badań było sprawdzenie, czy grupy osób uzależnionych od alkoholu i nieuzależnionych różnią się w zakresie retrospektywnej oceny postaw rodziców (badanie 1) oraz czy osoby uzależnione od alkoholu mające i niemające uzależnionego rodzica różnią się w retrospektywnej ocenie ich postaw (badanie 2). Materiał i metoda: W badaniu 1 uczestniczyło 121 osób uzależnionych od alkoholu i 121 osób bez uzależnienia (w obu grupach po 37 kobiet i 84 mężczyzn). W badaniu 2 udział wzięło 221 osób uzależnionych od alkoholu (55 kobiet i 166 mężczyzn). Zastosowano Kwestionariusz Retrospektywnej Oceny Postaw Rodziców (KPR-Roc) Mieczysława Plopy oraz Test Rozpoznawania Problemów Alkoholowych AUDIT. Wyniki: W badaniu 1 wykazano, iż osoby uzależnione od alkoholu uzyskują wyższe wyniki niż nieuzależnione w zakresie zmiennych Matka Ochranianie, Ojciec Wymaganie i Ojciec Niekonsekwencja oraz niższe w zakresie zmiennych Ojciec Akceptacja/Odrzucenie i Ojciec Autonomia. W badaniu 2 stwierdzono, że kobiety uzależnione od alkoholu, w których rodzinie pochodzenia występowało uzależnienie od alkoholu, osiagają niższe wyniki w zakresie zmiennych Matka Akceptacja/Odrzucenie, Ojciec Akceptacja/Odrzucenie, Ojciec Autonomia i Ojciec Ochranianie w porównaniu z kobietami uzależnionymi, w których rodzinie ono nie występowało. Z kolei mężczyźni uzależnieni od alkoholu, w których rodzinie pochodzenia występowało uzależnienie od alkoholu, uzyskują niższe wyniki w zakresie zmiennej Ojciec Akceptacja/Odrzucenie oraz wyższe w zakresie zmiennych Ojciec Wymaganie i Ojciec Niekonsekwencja w porównaniu z mężczyznami uzależnionymi, w których rodzinie ono nie występowało. Wnioski: Osoby uzależnione od alkoholu bardziej niekorzystnie niż nieuzależnione oceniają postawę ojca. Posiadanie przez osoby uzależnione od alkoholu uzależnionego rodzica różnicuje głównie retrospektywną ocenę ojca.

Słowa kluczowe: postawy rodzicielskie, postawa rodzicielska matki, postawa rodzicielska ojca, uzależnienie od alkoholu 


\section{INTRODUCTION}

$\mathrm{T}$ aking into consideration many theories, including John Bowlby's attachment theory, it is generally assumed that each person develops through a dialogue with another human being, by means of the other person, and mostly for the other person. The optimal relationship is a crucial factor for sustaining mental health (Świtała, 2002). Along with a child's development, a process called internalisation takes place. It is based on a transition of certain external aspects into the internal psychic structure - experiences concerning significant others associated with specific emotional states become internalised (Świtała, 2002). What is important for healthy development is having a representation of an available, responsive and supporting child's autonomy parent (Bowlby, 2007; Senator, 2012). Bowlby claimed that repetitive interactions between a child and its caregivers are a source of knowledge about the world of interpersonal relationships, which is marked in the mind as an internal working model; it is a relatively permanent element of personality, storing early relationship experiences with the caregiver and specifying significant parts of self-image (Bowlby, 2007; Wallin, 2011). Internal working models regulate building closeness and intimate relationships because the history of attachment relationships originated in childhood has an influence on the depth and form of attachment among adults (Bowlby, 2007; Wallin, 2011). According to contemporary researchers, the attachment theory is very significant for understanding correct development and aetiology of mental disorders in all developmental stages (Bomba, 2008). The correlation between attachment and one's development is explained by four, non-mutually exclusive, mechanisms (Senator, 2012). Firstly, it is claimed that - and it has been proved in neurobiological studies - the infantile experiences, including those regarding the attachment, have an influence on child's brain development, which results in long-term changes at a neuronal level. The bond between the child and its caregiver fundamentally moulds the structure and functions of the limbic system and the right hemisphere of the brain, significant for instance in terms of emotional processing (Schore, 2009; Senator, 2012; Żechowski and Namysłowska, 2008). Secondly, the attachment relationship may be a base for creating the ability to regulate emotions because of relationship concurrent process of internalising the ways of affect regulation (Senator, 2012). It is assumed that effective emotional self-regulation is connected with the secure type of attachment, whereas the insecure attachment styles are related with emotional regulation disorders (Żechowski and Namysłowska, 2008), which are contemporarily seen as ones of the most basic mechanisms of all mental disorders (Schore, 2009). The third mechanism explaining the correlation between attachment and further development includes behavioural regulation and synchrony. By means of observing and interacting with the caregiver, the child learns maintaining a relationship and

\section{WSTĘP}

$\mathrm{N}$ a gruncie wielu teorii, również teorii przywiązania, której twórcą jest John Bowlby, zakłada się, że każda osoba rozwija się w dialogu $\mathrm{z}$ drugim człowiekiem, poprzez drugiego człowieka i w dużej mierze dla niego. Optymalna relacja jest zasadniczym warunkiem zdrowia psychicznego (Świtała, 2002). Wraz z rozwojem dziecka zachodzi proces internalizacji, polegający na przechodzeniu aspektów świata zewnętrznego do wewnętrznej struktury psychicznej - uwewnętrznione zostają doświadczenia związane ze znaczącymi osobami, skojarzonymi z konkretnymi stanami emocjonalnymi (Świtała, 2002). Ważne dla zdrowego rozwoju jest posiadanie reprezentacji rodzica dostępnego, responsywnego czy wspierającego autonomię dziecka (Bowlby, 2007; Senator, 2012). Bowlby twierdził, że powtarzające się interakcje dziecka $\mathrm{z}$ opiekunami są źródłem wiedzy o świecie relacji międzyludzkich, która zostaje zarejestrowana w umyśle jako wewnętrzny model operacyjny; jest on względnie trwałym elementem osobowości, przechowującym wczesne doświadczenia w relacji z opiekunem i określającym istotne części obrazu siebie (Bowlby, 2007; Wallin, 2011). Wewnętrzne modele operacyjne regulują budowanie bliskości oraz intymnych związków, gdyż historia relacji przywiązaniowych w dzieciństwie wpływa na głębokość i formę przywiązania dorosłych (Bowlby, 2007; Wallin, 2011).

Zdaniem współczesnych badaczy koncepcja przywiązania ma ogromne znaczenie dla rozumienia prawidłowego rozwoju i powstawania zaburzeń psychicznych we wszystkich okresach rozwojowych (Bomba, 2008). Związek między przywiązaniem a dalszym rozwojem wyjaśniany jest przez cztery, niewykluczające się wzajemnie, mechanizmy (Senator, 2012). Po pierwsze uważa się - i znajduje to potwierdzenie w badaniach neurobiologicznych - że doświadczenia wczesnodziecięce, także te dotyczące przywiązania, wpływają na rozwijający się mózg dziecka, co skutkuje długotrwałymi zmianami na poziomie neuronalnym. Więź dziecka $z$ opiekunem w fundamentalny sposób kształtuje strukturę i funkcje układu limbicznego i prawej półkuli mózgu, istotnych m.in. dla przetwarzania emocji (Schore, 2009; Senator, 2012; Żechowski i Namysłowska, 2008). Po drugie relacja przywiązaniowa może być podstawą kształtowania się zdolności do regulacji emocji, ze względu na towarzyszący relacji proces internalizowania sposobów regulowania afektu (Senator, 2012). Przyjmuje się, że efektywna samoregulacja emocji związana jest $\mathrm{z}$ ufnym przywiązaniem, natomiast pozabezpieczne wzorce przywiązania mają związek z zaburzeniami regulacji emocji (Żechowski i Namysłowska, 2008), uważanymi współcześnie za jeden $\mathrm{z}$ podstawowych mechanizmów wszystkich zaburzeń psychicznych (Schore, 2009). Trzeci mechanizm wyjaśniający związek między przywiązaniem a dalszym rozwojem obejmuje behawioralną regulację i synchronię. Obserwując opiekuna i wchodząc z nim w interakcje, dziecko uczy się relacji z drugim człowiekiem i rozumienia go, wykształca umiejętności społeczne (Senator, 2012) 
understanding another person, develops social skills (Senator, 2012) and gains an ability to mentalise (Allen et al., 2014). It is worth mentioning that a conducting factor here is the secure attachment (Allen et al., 2014; Senator, 2012). The last, fourth mechanism regards the establishment of self and caregiver's representations, which includes beliefs and expectations; only the secure attachment style allows a person to create a positive representation of self and others (Tryjarska, 2012; Wallin, 2011).

Taking the above into consideration, it is clear that the attachment theory implies an incredible child's dependence from their caregivers and at the same time it explains the contemporarily highlighted opinion that the interpersonal trauma originating from childhood may play - in the context of psychopathology forming - a bigger role than genetic, constitutional or social factors (Schore, 2009). It sheds new light on the role of parents as the attachment figures as well as on parental attitudes for a child's development.

The attitude is defined as a relatively permanent tendency to take a positive or negative stance towards a specific object which links three components: cognitive (being a collection of beliefs regarding this object), affective (including the emotions associated with the object) and behavioural (which finds an expression in the behaviours towards the object) (Wojciszke, 2007). The parental attitude is described as an 'acquired cognitive-striving-affective structure orienting the parents' behaviour towards their children' (Ziemska, 1969, p. 33). In other words, it is a way of parents' reacting including a set of preconceptions and beliefs, experiences and behaviours in relation to the child (Ziemska, 1969). It is claimed that the most significant element of a parental attitude is the emotional component (Plopa, 2007). Development of attitude depends on a large number of factors. The experiences originating from one's family of origin, subjective determinants of parents, the quality of the marital relationship or subjective determinants of a child appear to be the most important factors (Plopa, 2007). The classifications created by Maria Ziemska (1969) and Mieczysław Plopa (2007) seem to be the most well-known and most frequently quoted ones. Due to the use of the below-mentioned research tool in the author's study, the latter typology will be described in details.

Plopa (2007) mentions five parental attitudes:

1. acceptance-rejection attitude - on the one hand, the accepting attitude includes the mutual empathy, trust and tolerance; the parent makes a space for the child's development based on a sense of security, freedom for feelings exchange and respect for the child and its needs; it also acknowledges child's weaknesses and strong points; on the other hand, the rejection attitude includes certain distance and emotional coldness, inability to read the child's needs or to perceive its subjectivity as well as negative reactions to any attempts of the child to get closer to the parent;

2. excessively demanding - it may be characterised by ruthless attempts to fit the child to an inflexible, authoritarian i zdolność do mentalizacji (Allen et al., 2014). Warto zaznaczyć, że sprzyja temu ufne przywiązanie (Allen et al., 2014; Senator, 2012). Ostatni, czwarty mechanizm odnosi się do tworzenia $\mathrm{w}$ ramach relacji przywiązania reprezentacji siebie i opiekuna, zawierających przekonania i oczekiwania; tylko bezpieczny wzór przywiązania pozwala jednostce stworzyć pozytywną reprezentację siebie i drugiego człowieka (Tryjarska, 2012; Wallin, 2011).

Powyższe rozważania ukazują, iż koncepcja więzi zakłada niezwykłą zależność dziecka od opiekunów, a jednocześnie tłumaczy podkreślany obecnie pogląd, że uraz pochodzenia interpersonalnego przebyty w dzieciństwie może odgrywać - w kontekście tworzenia się psychopatologii - większą rolę niż czynniki genetyczne, konstytucyjne czy społeczne (Schore, 2009). Rzuca to nowe światło na rolę rodziców jako figur przywiązania i na znaczenie postaw rodzicielskich dla rozwoju dziecka.

Postawę definiuje się jako względnie trwałą tendencję do pozytywnego lub negatywnego ustosunkowania się wobec określonego obiektu, łączącą trzy komponenty: poznawczy (który jest zbiorem przekonań na temat obiektu), afektywny (który zawiera w sobie emocje kojarzone $\mathrm{z}$ obiektem) i behawioralny (który wyraża się w zachowaniach wobec obiektu) (Wojciszke, 2007). Postawa rodzicielska jest zaś ujmowana jako „nabyta struktura poznawczo-dążeniowo-afektywna, ukierunkowująca zachowanie się rodziców wobec dziecka" (Ziemska, 1969, s. 33), czyli jako sposób reagowania rodziców obejmujący zbiór sądów i przekonań, przeżyć oraz zachowań związanych z dzieckiem (Ziemska, 1969). Zakłada się, że najbardziej istotnym elementem postawy rodzicielskiej jest komponent uczuciowy (Plopa, 2007). Kształtowanie się postaw zależy od licznych czynników, spośród których za najważniejsze uważa się doświadczenia $\mathrm{z}$ własnej rodziny pochodzenia, podmiotowe uwarunkowania rodziców, jakość relacji małżeńskiej czy podmiotowe uwarunkowania dziecka (Plopa, 2007). Do najbardziej znanych i najczęściej cytowanych klasyfikacji postaw rodzicielskich należą klasyfikacje Marii Ziemskiej (1969) i Mieczysława Plopy (2007). Z uwagi na wykorzystane w badaniach własnych narzędzie pomiaru poniżej opisana zostanie druga $\mathrm{z}$ wymienionych typologii.

Plopa (2007) wyróżnia pięć postaw rodzicielskich:

1. postawę akceptacji-odrzucenia - nastawienie akceptujące obejmuje obustronną empatię, zaufanie i tolerancję; rodzic stwarza dziecku przestrzeń do rozwoju opartą na poczuciu bezpieczeństwa, swobodzie wymiany uczuć oraz szacunku dla dziecka i jego potrzeb, a także uznaje wady i zalety swojego dziecka; na drugim biegunie znajduje się nastawienie odrzucające, które obejmuje dystans i chłód emocjonalny, nieumiejętność odczytywania potrzeb dziecka, niedostrzeganie jego podmiotowości i negatywne reakcje na wszelkie próby zbliżenia się do rodzica;

2. postawę nadmiernie wymagającą - charakteryzuje się ona bezwzględnymi próbami dopasowania dziecka do sztywnego, autorytarnego modelu wychowania z surową 
model of parenting with a strict and fastidious assessment of child's activities; in a relationship there is a lack of understanding regarding child's needs, especially the need of autonomy or individuality;

3. autonomy attitude - the parent's behaviour is flexible and adequate regarding the developmental needs of a child; the parent accepts the child to the fullest and respects its individuality; strengthens the unaided attempts to solve problems and impartially tries to give advice in case child needs it;

4. inconsequence attitude - it is revealed in a volatile attitude towards the child (conditioned by parent's passing mood or well-being); the parent is perceived by the child as unpredictable, vociferous and nervous, which may lead to establishing an emotional distance and closure against the parent and later results in an increase of parent's annoyance and frustration as well as in an escalation of the earlier difficulties;

5. excessively protective attitude - the parent expresses exaggerated concerns and involvement in child's matters and a lack of belief regarding its self-reliance, which results from an inability to accept the child's individuality; simultaneously the parent does not discern the influence of his/her own behaviour on creating conflicts and child's distancing.

The majority of systemic concepts concerning the aetiology of alcohol dependence include also the assumptions regarding the incorrect functioning of parental figures among individuals with alcohol dependence (Gąsior, 2012; Grzegorzewska, 2013). Fulfilling the parental roles seems to be one of the most important factors, among many other, protecting from psychopathology (Gąsior, 2012; Plopa, 2007). The ways of fulfilling the parental role are frequently described by the use of two dimensions: the first one is the attachment and support connected with the parental love, closeness and care during difficult situations experienced by the child, whereas the second one is controlling, which stands for both: being interested in the child as well as the skilful implementation of discipline and development of self-discipline (Cierpiałkowska and Grzegorzewska, 2016; Gąsior, 2012). Optimal parent's behaviours involve both: a high level of support and control (Grzegorzewska, 2011). According to the studies conducted by Grzegorzewska (2011), among children having an alcohol-dependent father, who did not undertake any treatment, the level of bond and control of both parents was the lowest in comparison with children whose father was addicted to alcohol but started treatment or with children with no family history of alcohol addiction. According to Sroufe (see: Gąsior, 2012), the most precarious parental behaviours in relationships with children are: strict treating, entwined with hostility and rejection, and the lack of proper control and discipline. In other words: in line with the attachment theory, but also in compliance with the assumptions regarding the model of developmental psychopathology, parents' abilities and engagement in terms of care (love) and i drobiazgową oceną podejmowanych przez dziecko aktywności; w relacji brakuje zrozumienia potrzeb dziecka, szczególnie potrzeby autonomii czy indywidualności;

3. postawę autonomii - zachowanie rodzica jest elastyczne i adekwatne do potrzeb rozwojowych dziecka; rodzic w pełni akceptuje dziecko i szanuje jego odrębność, wzmacnia samodzielne próby rozwiązywania problemów i stara się bezstronnie służyć radą, gdy dziecko wykazuje taką potrzebę;

4. postawę niekonsekwentną - ujawnia się ona w (uwarunkowanym chwilowym nastrojem lub samopoczuciem rodzica) zmiennym ustosunkowaniu do dziecka; rodzic jest postrzegany przez dziecko jako nieprzewidywalny, krzykliwy i nerwowy, co może skutkować powstaniem dystansu emocjonalnego i zamknięciem się na rodzica, a w dalszej konsekwencji wzrostem jego irytacji i frustracji oraz pogłębieniem wcześniejszych trudności;

5. postawę nadmiernie ochraniającą - rodzic wykazuje przesadną troskę i zaangażowanie w sprawy dziecka oraz brak wiary w jego samodzielność, co wynika z nieumiejętności zaakceptowania odrębności dziecka; jednocześnie rodzic nie dostrzega wpływu własnego zachowania na powstawanie konfliktów i dystansowanie się dziecka. Większość koncepcji systemowych dotyczących genezy uzależnienia od alkoholu obejmuje również założenia odnoszące się do nieprawidłowego funkcjonowania postaci rodzicielskich osób uzależnionych (Gąsior, 2012; Grzegorzewska, 2013). Sprawowanie funkcji rodzicielskich traktuje się jako jeden z najważniejszych spośród licznych czynników ryzyka psychopatologii i czynników chroniących (Gąsior, 2012; Plopa, 2007). Sposoby sprawowania funkcji rodzicielskich sprowadza się często do dwóch wymiarów: pierwszy to więź i wsparcie, odnoszące się do rodzicielskiej miłości, bliskości i opieki w trudnych dla dziecka sytuacjach, drugi zaś to kontrola, oznaczająca zarówno zainteresowanie dzieckiem, jak i umiejętne wprowadzanie dyscypliny i kształtowanie samodyscypliny (Cierpiałkowska i Grzegorzewska, 2016; Gąsior, 2012). Optymalne zachowanie rodzica obejmuje interakcję wysokiego poziomu wsparcia i kontroli (Grzegorzewska, 2011). Jak wykazały badania Grzegorzewskiej (2011), u dzieci mających uzależnionego od alkoholu i nieleczącego się ojca poziom więzi i kontroli obojga rodziców był najniższy w porównaniu z dziećmi, których uzależniony ojciec podjął leczenie, i dziećmi bez historii uzależnienia w rodzinie. Jak przekonuje Sroufe (za: Gąsior, 2012), najbardziej zagrażającymi zachowaniami rodziców w relacjach z dziećmi są surowe, połączone $\mathrm{z}$ wrogością i odrzuceniem traktowanie oraz brak właściwej kontroli i dyscypliny. Innymi słowy: w myśl teorii więzi, ale również zgodnie z założeniami modelu psychopatologii rozwojowej, umiejętności i zaangażowanie rodziców w zakresie opieki (miłości) i dyscypliny (kontroli) są kluczowe dla prawidłowego rozwoju dziecka i powinny być optymalnie dopasowane do wyłaniających się potrzeb i pragnień dziecka, różnych w zależności od etapu rozwojowego (Cierpiałkowska i Grzegorzewska, 2016). 
discipline (control) are crucial for proper child's development and ought to be optimally adapted to emerging needs and wishes of the child, which may be different depending on the particular developmental phase (Cierpiałkowska and Grzegorzewska, 2016).

The above-mentioned conclusions deriving from literature appear to be in accordance with the studies revealing a higher frequency of traumatic events and post-traumatic stress disorder among individuals with alcohol dependence (Dragan, 2008; Najavits, 2010) as well as with the results of the studies on assessment of parental attitudes in this clinical group, although it should be emphasised that there have not been many studies conducted on this issue so far. The authors point out that the most frequent perception of parents among the alcohol-dependent patients is as parents deprived of warmth, excessively protective and over-controlling (De Rick and Vanheule, 2006). Both mothers and fathers are perceived by the alcohol-dependent individuals in comparison with the non-dependent - as excessively protective, rejecting and characterised by a lower level of emotional warmth, whereby the mothers are described as even more excessively protective and emotionally warmer than the fathers (De Jong and Jacobs, 2010).

What is more, the studies conducted on adolescents also provide significant results regarding the correlation between the perception of parents and alcohol consumption. These studies reveal the fact that discerning a heavier disregard from a father and mother corresponds with an increase of problems connected with alcohol through intensification of the feeling of stress, whereas the higher level of perceived rejection from a father and experiencing oneself as unwanted are connected with the growth of pathological (connected with emotional states self-medication) reasons for alcohol drinking which can lead to problem drinking (Backer-Fulghum et al., 2012; Patock-Peckham and Morgan-Lopez, 2010). Perceiving mother as attentively caring is related to a reduction of pathological reasons for drinking by means of the increase of self-esteem and decrease of the level of stress (Backer-Fulghum et al., 2012). Furthermore, in the case of boys rejection by the mother as well as both parents excessive protectiveness connected with the intensification of antisocial symptoms may lead to problems with alcohol (Patock-Peckham and Morgan-Lopez, 2010). Despotic and deprived of warmth father's parental style as well as permissive style demonstrated by the parent who is of the same sex as the child are predictors of growth of problematic alcohol use, lower ability to self-regulate and intensification of depressive symptoms among boys and girls (Patock-Peckham and Morgan-Lopez, 2007, 2009; Patock-Peckham et al., 2001).

It is emphasised in the literature that the parents' influence on alcohol drinking among adolescent and adult children is important, but at the same time it is not unambiguous (Spooner, 1999; Visser et al., 2012). It is believed that among the family factors increasing the risk of psychoactive substance abuse there are also the factors connected with the
Powyższe wnioski z literatury wydają się pozostawać w zgodzie zarówno $\mathrm{z}$ badaniami stwierdzającymi większą częstotliwość wydarzeń traumatycznych i zespołu stresu pourazowego wśród osób uzależnionych od alkoholu (Dragan, 2008; Najavits, 2010), jak i z wynikami badań nad oceną postaw rodziców w tej grupie klinicznej, choć zaznaczyć należy, że takich badań jest niewiele. Autorzy podkreślają, iż najczęstsza wśród pacjentów nadużywających alkoholu jest percepcja własnych rodziców jako pozbawionych ciepła, nadopiekuńczych i nadmiernie kontrolujących (De Rick i Vanheule, 2006). I matki, i ojcowie postrzegani są przez osoby uzależnione od alkoholu - w porównaniu z nieuzależnionymi - jako nadmiernie chroniący, odrzucający i cechujący się mniejszym poziomem emocjonalnego ciepła, przy czym matki wspominane są jako bardziej nadmiernie chroniące i emocjonalnie cieplejsze niż ojcowie (De Jong i Jacobs, 2010).

Istotnych wniosków dostarczają również badania nad adolescentami dotyczące zależności między percepcją rodziców a spożywaniem alkoholu. Ukazują one, iż spostrzeganie większego lekceważenia przez ojca i matkę koresponduje ze wzrostem problemów związanych $\mathrm{z}$ alkoholem poprzez nasilenie poczucia stresu, natomiast wyższy poziom spostrzeganego odrzucenia przez ojca i przeżywanie siebie jako niechcianego wiążą się ze wzrostem patologicznych (związanych z samoleczeniem stanów emocjonalnych) przyczyn picia alkoholu, co może prowadzić do picia problemowego (Backer-Fulghum et al., 2012; Patock-Peckham i Morgan-Lopez, 2010). Spostrzeganie matki jako uważnie troszczącej się powiązane jest $\mathrm{z}$ kolei $\mathrm{z}$ redukcją patologicznych przyczyn picia poprzez zwiększenie poczucia własnej wartości i obniżenie poziomu stresu (Backer-Fulghum et al., 2012). Ponadto w przypadku chłopców odrzucenie przez matkę oraz nadopiekuńczość matki i ojca, wiążące się ze wzrostem objawów antyspołeczności, mogą prowadzić do problemów alkoholowych (Patock-Peckham i Morgan-Lopez, 2010). Despotyczny i pozbawiony ciepła styl rodzicielski ojca oraz styl pobłażliwy rodzica tej samej płci co dziecko są predyktorami wzrostu problemowego picia alkoholu, mniejszej zdolności do samoregulacji i nasilenia objawów depresyjnych u chłopców i dziewcząt (Patock-Peckham i Morgan-Lopez, 2007, 2009; Patock-Peckham et al., 2001). W literaturze podkreśla się, iż wpływ rodziców na spożywanie alkoholu przez nastoletnie i dorosłe dzieci jest ważny, ale też niejednoznaczny (Spooner, 1999; Visser et al., 2012). Do czynników rodzinnych zwiększających ryzyko nadużywania substancji psychoaktywnych należą czynniki związane z jakością relacji rodzic-dziecko: negatywne wzory komunikacji i brak komunikacji z dzieckiem, słabe więzi w rodzinie, brak zainteresowania aktywnościami dzieci i brak zaufania do rodziców, a także czynniki związane z modelowaniem (np. używanie substancji przez rodzica) - przy czym uznaje się, że czynniki związane z jakością relacji mają większy wpływ (Habib et al., 2010; McKay et al., 2011; Spooner, 1999). Osobnym zagadnieniem, obszernie poruszanym w literaturze, jest kwestia obrazu rodzica uzależnionego od alkoholu 
quality of parent-child relationship: negative communication patterns and a lack of communication with child, weak family bonds, a lack of interests in activities performed by children and a lack of trust to parents as well as the factors regarding the role modelling (for example substance abuse by a parent) - whereby it is assumed that the factors connected with the relationship quality have a more serious impact (Habib et al., 2010; McKay et al., 2011; Spooner, 1999). A separate issue, extensively described in the literature, is a problem of the image of alcohol-dependent parent and their influence on the child's and adult child's functioning in various spheres of life (Gąsior, 2011; Grzegorzewska, 2013; Kelley et al., 2010, 2008, 2005; Kroll, 2004). It is assumed that the psychopathological symptoms - including alcohol abuse - in the group of individuals having an alcoholdependent parent are not a determinist phenomenon, but only probabilistic. It is also believed that it is necessary to take into consideration complex relationships between individuality as well as the person's resources and risk factors emerging at different stages of development (Grzegorzewska, 2011). Originating from a dysfunctional family characterised by a negative family dynamics or occurrences of negative events or interactions between children and parents is claimed to be a more significant predictor of stress and non-adaptive behaviours than the fact of originating from a family with alcohol problem itself (Golińska, 2010). It is also revealed in Gąsior's (2012) typology of adult children of alcoholics (ACA) which encompasses both the ACA category from families with high dysfunctionality (with a very negative image of the father and his parental activities and a negative image of the mother and her activities) and the ACA category from families characterised by low dysfunctionality (with a barely negative image of the father and his parental activities and a positive image of the mother and her activities). In other words, parent's alcohol abuse does not necessarily have to lead to pathology in child's development - also due to the fact that the protective role can be played by the non-drinking parent (Cierpiałkowska and Grzegorzewska, 2016). However, individuals with a family history of alcohol addiction are more exposed to negative experiences, including the relational traumas, and this danger differs depending on the sex of the alcohol-dependent parent (Cierpiałkowska and Grzegorzewska, 2016; Gąsior, 2012). Moreover, the negative events may be more severe for these individuals than to individuals with no family history of alcohol addiction - because of a higher probability of emotional unavailability of the parent (drinking and/or non-drinking), a lack of support or positive patterns in terms of family functioning (Cierpiałkowska and Grzegorzewska, 2016).

Taking into account the small number of studies regarding the parental assessment in the group of the alcohol-dependent, the author decided to check in her own research whether the alcohol-dependent and non-dependent individuals differ in terms of retrospectively assessed mother's and father's attitudes as well as if the retrospectively oraz jego wpływu na funkcjonowanie dziecka i dorosłego dziecka w różnych obszarach życia (Gąsior, 2011; Grzegorzewska, 2013; Kelley et al., 2010, 2008, 2005; Kroll, 2004). Uważa się, że symptomy psychopatologiczne - również nadużywanie alkoholu - w grupie osób mających uzależnionego rodzica nie są zjawiskiem deterministycznym, lecz probabilistycznym i że konieczne jest uwzględnianie złożonych związków między indywidualnością i zasobami jednostki a czynnikami ryzyka występującymi na poszczególnych etapach rozwoju (Grzegorzewska, 2011). Pochodzenie z rodziny dysfunkcyjnej, charakteryzującej się negatywną dynamiką rodzinną czy występowaniem negatywnych zdarzeń lub interakcji dzieci z rodzicami uważane jest za istotniejszy predyktor stresu i nieadaptacyjnego przystosowania niż sam fakt pochodzenia $\mathrm{z}$ rodziny $\mathrm{z}$ problemem alkoholowym (Golińska, 2010).

Ukazuje to również typologia dorosłych dzieci alkoholików (dda) Gąsiora (2012), która obejmuje zarówno kategorię dda $\mathrm{z}$ rodzin o wysokiej dysfunkcjonalności ( $\mathrm{z}$ wysoce negatywnym obrazem ojca i jego praktyk rodzicielskich oraz negatywnym obrazem matki i jej praktyk), jak i kategorię dda $\mathrm{z}$ rodzin o niskiej dysfunkcjonalności (z mało negatywnym obrazem ojca i jego praktyk rodzicielskich oraz pozytywnym obrazem matki i jej praktyk) oraz dda z rodzin o zróżnicowanym nasileniu dysfunkcjonalności ( $\mathrm{z}$ wysoce negatywnym obrazem ojca i jego praktyk rodzicielskich oraz pozytywnym obrazem matki i jej praktyk). Innymi słowy, nadużywanie alkoholu przez rodzica nie musi automatycznie prowadzić do patologizacji rozwoju dziecka także z uwagi na fakt, że ochronną rolę może odgrywać rodzic niepijący (Cierpiałkowska i Grzegorzewska, 2016). Niemniej jednak osoby pochodzące $\mathrm{z}$ rodzin $\mathrm{z}$ problemem alkoholowym są bardziej narażone na negatywne doświadczenia, w tym urazy pochodzenia relacyjnego, a zagrożenie to różni się w zależności od płci pijącego rodzica (Cierpiałkowska i Grzegorzewska, 2016; Gąsior, 2012). Ponadto negatywne wydarzenia mogą być dla tych osób bardziej dotkliwe niż dla osób bez historii uzależnienia w rodzinie ze względu na większe prawdopodobieństwo emocjonalnej niedostępności rodzica (pijącego i/lub niepijącego), braku wsparcia i braku pozytywnych wzorców funkcjonowania rodziny (Cierpiałkowska i Grzegorzewska, 2016).

Biorąc pod uwagę małą liczbę badań nad oceną rodzica w grupie osób uzależnionych od alkoholu, w badaniach własnych postanowiono sprawdzić, czy osoby uzależnione i nieuzależnione różnią się w zakresie retrospektywnej oceny postaw matki i ojca oraz czy retrospektywna ocena postaw rodzica w grupie osób uzależnionych od alkoholu różni się w zależności od posiadania (lub nie) uzależnionego rodzica. W artykule zaprezentowane zostaną dwa badania: w pierwszym (badanie 1) uczestniczyły osoby uzależnione od alkoholu i osoby nieuzależnione - przeprowadzono analizę różnic w zakresie retrospektywnej oceny rodziców; drugie (badanie 2) objęło osoby uzależnione od alkoholu przeprowadzono analizę różnic w zakresie retrospektywnej oceny rodziców w zależności od występowania uzależnienia 
assessed parental attitudes among the alcohol-dependent individuals differ depending on having (or not having) an addicted parent. The results from the two studies will be demonstrated in the article. In the first study (study 1) participated alcohol-dependent and non-dependent individuals - it was an analysis of differences in terms of retrospectively assessed parental attitudes; the second study (study 2) was conducted over alcohol-dependent individuals - it was an analysis of differences carried out regarding the retrospectively assessed parental attitudes depending on the occurrence of addiction in the family history. It seems that broadening knowledge connected with the assessment of parental attitudes performed by the individuals with alcohol dependence may have an important justification both theoretically - as it extends the clinical image of an alcohol-dependent individual by those aspects of intrapsychic functioning, which in general can be connected with addiction itself, self-image or image of others, as well as practical - through determining the directions of advanced therapeutic work with the addicted patients.

Based on the studies in which it was observed that both mothers and fathers are perceived by the individuals abusing alcohol or with alcohol dependence - in comparison with the individuals with no alcohol dependence - as excessively protective, rejecting, negligent and characterised by a low level of emotional warmth (Backer-Fulghum et al., 2012; De Jong and Jacobs, 2010; De Rick and Vanheule, 2006; Patock-Peckham and Morgan-Lopez, 2010), it was assumed that the alcohol-dependent individuals in comparison with those non-dependent (study 1) will assess their parents as less accepting and more rejecting, more demanding and controlling, more inconsequent and excessively protective. Similarly in study 2 it was assumed that the alcohol-dependent individuals having an addicted parent will assess their parents as less accepting, more rejecting, more demanding and controlling, more inconsequent and excessively protective. The potential protective role and positive assessment regarding the non-drinking parent is frequently emphasised in the literature (Cierpiałkowska and Grzegorzewska, 2016). In the alcohol-dependent group there was a prevalence of people having an addicted father, but there were also people who had an addicted mother or both of the parents were addicted. Due to the large discrepancies concerning the number of respondents in particular subgroups and inability to conduct more advanced calculations, taking into account the sex of the parent with alcohol dependence, the author decided to formulate more general hypotheses in study 2 .

\section{MATERIALS AND METHODS}

\section{Participants}

\section{Study 1}

121 alcohol-dependent and 121 non-dependent individuals took part in the research, matching in terms of sex (respectively 37 women and 84 men in each group), age (in $\mathrm{w}$ rodzinie pochodzenia. Wydaje się, że pogłębianie wiedzy związanej z oceną postaw rodziców dokonywaną przez osoby uzależnione od alkoholu ma ważne uzasadnienie zarówno teoretyczne - poszerza bowiem obraz kliniczny osoby uzależnionej o te aspekty funkcjonowania intrapsychicznego, które w szerokim rozumieniu mogą mieć związek z samym uzależnieniem, obrazem siebie czy obrazem drugiego człowieka, jak i praktyczne - poprzez wyznaczanie kierunków zaawansowanej pracy terapeutycznej z osobami uzależnionymi.

Bazując na badaniach, w których zauważono, że zarówno matki, jak i ojcowie spostrzegani są przez osoby nadużywające alkoholu lub uzależnione - w porównaniu z osobami bez uzależnienia - jako nadmiernie chroniący, odrzucający, lekceważący i cechujący się mniejszym poziomem emocjonalnego ciepła (Backer-Fulghum et al., 2012; De Jong i Jacobs, 2010; De Rick i Vanheule, 2006; Patock-Peckham i Morgan-Lopez, 2010), założono, iż osoby uzależnione od alkoholu w porównaniu z nieuzależnionymi (badanie 1) będą oceniały swoich rodziców jako mniej akceptujących i bardziej odrzucających, bardziej wymagających i kontrolujących, bardziej niekonsekwentnych oraz nadmiernie ochraniających. Podobnie w badaniu 2 założono, że osoby uzależnione mające uzależnionego rodzica będą oceniały swoich rodziców jako mniej akceptujących i bardziej odrzucających, bardziej wymagających i kontrolujących, bardziej niekonsekwentnych oraz nadmiernie ochraniających. W literaturze podkreśla się potencjalną ochronną rolę i pozytywną ocenę rodzica niepijącego (Cierpiałkowska i Grzegorzewska, 2016). W grupie uzależnionych osób dominowały osoby mające uzależnionego ojca, lecz były również osoby mające uzależnioną matkę lub oboje rodziców. Z uwagi na duże rozbieżności w liczebności poszczególnych podgrup i niemożność przeprowadzenia bardziej zaawansowanych obliczeń z uwzględnieniem płci uzależnionego rodzica podjęto decyzję o ogólniejszym sformułowaniu hipotez w badaniu 2.

\section{MATERIA I I METODA}

\section{Osoby badane}

\section{Badanie 1}

W badaniu wzięło udział 121 osób uzależnionych od alkoholu i 121 osób bez uzależnienia od alkoholu, dopasowanych pod względem płci (po 37 kobiet i 84 mężczyzn w każdej grupie), wieku (w grupie osób uzależnionych: $M=42,60$; odchylenie standardowe, standard deviation, $S D=11,39$; w grupie osób nieuzależnionych: $M=41,63$; $S D=11,90$ ) oraz posiadania lub nieposiadania uzależnionego rodzica (tab. 1). Wobec grupy kontrolnej zastosowano procedurę doboru metodą kuli śniegowej, a następnie doboru celowego do wcześniej zebranej grupy osób uzależnionych. W grupie kontrolnej wykorzystano Test Rozpoznawania Problemów Alkoholowych AUDIT (Alcohol Use Disorder Identification Test) w celu identyfikacji osób pijących w sposób ryzykowny, szkodliwy lub uzależnionych 


\begin{tabular}{|c|c|c|c|c|c|c|}
\hline & \multicolumn{3}{|c|}{$\begin{array}{l}\text { Addicted people } \\
\text { Osoby uzależnione }\end{array}$} & \multicolumn{3}{|c|}{$\begin{array}{l}\text { Non-addicted people } \\
\text { Osoby nieuzależnione }\end{array}$} \\
\hline & $\begin{array}{c}\text { Women } \\
\text { Kobiety } \\
n=37 \\
\end{array}$ & $\begin{array}{c}\text { Men } \\
\text { Mężczyźni } \\
n=\mathbf{8 4} \\
\end{array}$ & $\begin{array}{c}\text { In total } \\
\text { Ogółem } \\
n=121 \\
\end{array}$ & $\begin{array}{c}\text { Women } \\
\text { Kobiety } \\
\boldsymbol{n}=\mathbf{3 7} \\
\end{array}$ & $\begin{array}{c}\text { Men } \\
\text { Mężczyźni } \\
\boldsymbol{n}=\mathbf{8 4} \\
\end{array}$ & $\begin{array}{c}\text { In total } \\
\text { Ogótem } \\
n=121 \\
\end{array}$ \\
\hline $\begin{array}{l}\text { Age, } M \text { (SD) } \\
\text { Wiek, M (SD) }\end{array}$ & $43.57(10.48)$ & $42.18(11.80)$ & $42.60(11.39)$ & $43.27(10.14)$ & $40.90(12.56)$ & $41.63(11.90)$ \\
\hline \multicolumn{7}{|l|}{$\begin{array}{l}\text { Education, } n(\%) \\
\text { Wyksztakcenie, } \mathrm{n}(\%)\end{array}$} \\
\hline $\begin{array}{l}\text { Primary } \\
\text { Podstawowe }\end{array}$ & $5(13 \%)$ & $5(6 \%)$ & $10(8 \%)$ & $0(0 \%)$ & $1(1 \%)$ & $1(1 \%)$ \\
\hline $\begin{array}{l}\text { Vocational } \\
\text { Zawodowe }\end{array}$ & $11(30 \%)$ & $25(30 \%)$ & $36(30 \%)$ & $3(8 \%)$ & $15(18 \%)$ & $18(15 \%)$ \\
\hline $\begin{array}{l}\text { Secondary } \\
\text { Srednie }\end{array}$ & $17(46 \%)$ & 37 (44\%) & $54(47 \%)$ & $22(60 \%)$ & 37 (44\%) & $59(49 \%)$ \\
\hline $\begin{array}{l}\text { Higher } \\
\text { Wyżzze }\end{array}$ & $4(11 \%)$ & $17(20 \%)$ & $21(17 \%)$ & $12(32 \%)$ & $31(37 \%)$ & $43(35 \%)$ \\
\hline \multicolumn{7}{|l|}{$\begin{array}{l}\text { Addiction in the family, } n(\%) \\
\text { Uzależnienie w rodzinie, } \mathrm{n}(\%)\end{array}$} \\
\hline $\begin{array}{l}\text { Non-addicted parent } \\
\text { Nieuzależniony rodzic }\end{array}$ & $24(65 \%)$ & $72(86 \%)$ & $96(79 \%)$ & $24(65 \%)$ & $72(86 \%)$ & $96(79 \%)$ \\
\hline $\begin{array}{l}\text { Addicted parent } \\
\text { Uzależniony rodzic }\end{array}$ & $13(35 \%)$ & $12(14 \%)$ & $25(21 \%)$ & $13(35 \%)$ & $12(14 \%)$ & $25(21 \%)$ \\
\hline \multicolumn{7}{|l|}{$\begin{array}{l}\text { including: } \\
\text { w tym: }\end{array}$} \\
\hline $\begin{array}{l}\text { Addicted father } \\
\text { Uzależniony ojciec }\end{array}$ & $10(27 \%)$ & $11(13 \%)$ & $21(17 \%)$ & $10(27 \%)$ & $11(13 \%)$ & $21(17 \%)$ \\
\hline $\begin{array}{l}\text { Both parents addicted } \\
\text { Uzależnieni oboje rodzice }\end{array}$ & $3(8 \%)$ & $1(1 \%)$ & $4(3 \%)$ & $3(8 \%)$ & $1(1 \%)$ & $4(3 \%)$ \\
\hline \multicolumn{7}{|l|}{$\begin{array}{l}\text { Civil partnership, } n(\%) \\
\text { Zwiqzek partnerski, } \mathrm{n}(\%)\end{array}$} \\
\hline $\begin{array}{l}\text { Being currently in a relationship } \\
\text { Bycie obecnie w zwiqzku }\end{array}$ & $23(62 \%)$ & $53(63 \%)$ & $76(63 \%)$ & $30(81 \%)$ & $72(86 \%)$ & $102(84 \%)$ \\
\hline $\begin{array}{l}\text { Not being currently in a relationship } \\
\text { Niebycie obecnie w zwiqzzu }\end{array}$ & $14(38 \%)$ & 31 (37\%) & 45 (37\%) & $7(19 \%)$ & $12(14 \%)$ & 19 (16\%) \\
\hline
\end{tabular}

Tab. 1. Statistics and descriptive parameters in the groups of the alcohol-dependent and the non-dependent (study 1)

Tab. 1. Statystyki i parametry opisowe w grupach osób uzależnionych i nieuzależnionych od alkoholu (badanie 1)

the alcohol-dependent group: $M=42.60$; standard deviation, $S D=11.39$; in the non-dependent group: $M=41.63$; $S D=11.90)$ and having or not having an addicted parent (tab. 1).

A procedure of snowball sampling was used towards the control group. Afterwards a method of purposive sampling was applied on an earlier collected group of alcohol-dependent individuals. Alcohol Use Disorder Identification Test (AUDIT) was used in the control group in order to identify the individuals drinking in risky, damaging ways or the alcohol-dependent people (Fudała, 2009) - as a result, two individuals were excluded from this group as they scored 27 and 31 points.

\section{Study 2}

Bioethical Commission at Nicolaus Copernicus University in Torun by Ludwik Rydygier Collegium Medicum
(Fudała, 2009) - w rezultacie z grupy wykluczono dwie osoby, które uzyskały wyniki 27 i 31 punktów.

\section{Badanie 2}

Na prowadzenie badań wśród osób uzależnionych od alkoholu $(N=221$; grupa uczestnicząca w badaniu 2 obejmowała także 121 osób, których wyniki wykorzystano w badaniu 1), będących pacjentami stacjonarnych i ambulatoryjnych placówek lecznictwa odwykowego, uzyskano zgodę Komisji Bioetycznej Uniwersytetu Mikołaja Kopernika w Toruniu przy Collegium Medicum im. Ludwika Rydygiera w Bydgoszczy (nr zgody: KB30/2013). Grupa osób uzależnionych obejmowała 55 kobiet i 166 mężczyzn, ze średnią wieku $M=44,76(S D=11,34)$. 87 osób (39\%) miało uzależnionego rodzica, z czego u 63 osób (28\%) uzależnienie dotyczyło ojca, u 9 (4\%) - matki, a u 15 (7\%) - obojga rodziców. Osoby badane uczestniczyły w podstawowym programie leczenia uzależnień i utrzymywały abstynencję od alkoholu. Badania przeprowadzano grupowo, zawsze w obecności autorki 


\begin{tabular}{|c|c|c|c|}
\hline & $\begin{array}{l}\text { Addicted women } \\
\text { Kobiety uzależnione } \\
\quad(n=55)\end{array}$ & $\begin{array}{c}\text { Addicted men } \\
\text { Mężczyźni uzależnieni } \\
(n=166)\end{array}$ & $\begin{array}{l}\text { In total } \\
\text { Ogótem } \\
(N=221)\end{array}$ \\
\hline $\begin{array}{l}\text { Age, } M(S D) \\
\text { Wiek, M (SD) }\end{array}$ & $46.13(10.17)$ & $44.31(11.70)$ & 44.76 (11.34) \\
\hline \multicolumn{4}{|l|}{$\begin{array}{l}\text { Education, } n(\%) \\
\text { Wyksztakcenie, } \mathrm{n}(\%)\end{array}$} \\
\hline $\begin{array}{l}\text { Primary } \\
\text { Podstawowe }\end{array}$ & $8(14 \%)$ & 22 (13\%) & 30 (14\%) \\
\hline $\begin{array}{l}\text { Vocational } \\
\text { Zawodowe }\end{array}$ & 17 (31\%) & 70 (42\%) & 87 (39\%) \\
\hline $\begin{array}{l}\text { Secondary } \\
\text { Średnie }\end{array}$ & $23(42 \%)$ & $52(32 \%)$ & 75 (34\%) \\
\hline $\begin{array}{l}\text { Higher } \\
\text { Wyższe }\end{array}$ & $7(13 \%)$ & $22(13 \%)$ & $29(13 \%)$ \\
\hline \multicolumn{4}{|l|}{$\begin{array}{l}\text { Addiction in the family, } n(\%) \\
\text { Uzależnienie w rodzinie, } \mathrm{n}(\%)\end{array}$} \\
\hline $\begin{array}{l}\text { Non-addicted parents } \\
\text { Nieuzależnieni rodzice }\end{array}$ & $24(44 \%)$ & $110(66 \%)$ & $134(61 \%)$ \\
\hline $\begin{array}{l}\text { Addicted parent } \\
\text { Uzależniony rodzic }\end{array}$ & 31 (56\%) & $56(34 \%)$ & 87 (39\%) \\
\hline \multicolumn{4}{|l|}{$\begin{array}{l}\text { including: } \\
\text { w tym: }\end{array}$} \\
\hline $\begin{array}{l}\text { Addicted father } \\
\text { Uzależniony ojciec }\end{array}$ & $22(40 \%)$ & $41(25 \%)$ & $63(28 \%)$ \\
\hline $\begin{array}{l}\text { Addicted mother } \\
\text { Uzależniona matka }\end{array}$ & $4(7 \%)$ & $5(3 \%)$ & $9(4 \%)$ \\
\hline $\begin{array}{l}\text { Both parents addicted } \\
\text { Uzalezinieni oboje rodzice }\end{array}$ & $5(9 \%)$ & $10(6 \%)$ & $15(7 \%)$ \\
\hline \multicolumn{4}{|l|}{$\begin{array}{l}\text { Civil partnership, } n(\%) \\
\text { Zwiqzek partnerski, } \mathrm{n}(\%)\end{array}$} \\
\hline $\begin{array}{l}\text { Being currently in a relationship } \\
\text { Bycie obecnie w zwiqzku }\end{array}$ & 35 (64\%) & $100(60 \%)$ & 135 (61\%) \\
\hline $\begin{array}{l}\text { Not being currently in a relationship } \\
\text { Niebycie obecnie w zwiqzku }\end{array}$ & $20(36 \%)$ & $66(40 \%)$ & $86(39 \%)$ \\
\hline $\begin{array}{l}\text { The duration of the addiction [years], M (SD) } \\
\text { Czas trwania uzależnienia [lata], M (SD) }\end{array}$ & $10.69(7.26)$ & $15.1(9.24)$ & $14.04(9.00)$ \\
\hline $\begin{array}{l}\text { The duration of abstinence [weeks], M (SD) } \\
\text { Czas trwania abstynencji [tygodnie], M (SD) }\end{array}$ & 13.60 (13.09) & 10.39 (11.93) & $11.19(12.28)$ \\
\hline
\end{tabular}

Tab. 2. Statistics and descriptive parameters in the group of the alcohol-dependent (study 2)

Tab. 2. Statystyki i parametry opisowe w grupie osób uzależnionych od alkoholu (badanie 2)

the conduction of the research on the individuals with alcohol dependence $(N=221$; a total of 121 individuals took part in study 2, whose results were used in study 1), who were patients of inpatient and outpatient addiction treatment centres. The alcohol-dependent group included 55 women and 166 men, with the mean age $M=44.76$ $(S D=11.34) .87$ respondents $(39 \%)$ had an addicted parent, whereas among 63 respondents (28\%) the addiction concerned the father, among 9 respondents (4\%) - mother and among 15 (7\%) - both parents were addicted. Respondents participated in a basic programme of addiction treatment and maintained alcohol abstinence. The study was conducted in groups, always in the presence of the author of the article. Tab. 2 shows the statistics and descriptive parameters of the alcohol-dependent group. niniejszej pracy. W tab. 2 zaprezentowano statystyki i parametry opisowe grupy osób uzależnionych.

\section{Narzędzia badawcze}

W badaniach zastosowano Kwestionariusz Retrospektywnej Oceny Postaw Rodziców (KPR-Roc) Mieczysława Plopy (2005), złożony z dwóch wersji i służący do retrospektywnej oceny postaw matki i ojca, która jest dokonywana przez dorosłe dziecko. Każda z wersji zawiera po 50 stwierdzeń $\mathrm{z}$ pięciostopniowym formatem odpowiedzi. W KPR-Roc wyróżniono następujące wymiary:

- Akceptacja/Odrzucenie. Akceptacja: osoba badana pamięta rodzica jako bezwarunkowo ją akceptującego, prezentującego otwarte, spontaniczne zachowania, dającego 


\begin{tabular}{|c|c|c|c|c|c|c|c|}
\hline $\begin{array}{l}\text { Variable } \\
\text { Zmienna }\end{array}$ & $\begin{array}{l}\text { Females addicted } \\
\text { to alcohol, } M \text { (SD) } \\
\text { Kobiety uzależnione } \\
\text { od alkoholu, M (SD) }\end{array}$ & $\begin{array}{c}\text { Non-addicted } \\
\text { females, } M(S D) \\
\text { Kobiety nieuzależnione, } \\
M(S D)\end{array}$ & $\begin{array}{c}\text { Males addicted } \\
\text { to alcohol, } M \text { (SD) } \\
\text { Mężczyźni } \\
\text { uzależnieniod } \\
\text { alkoholu, M (SD) }\end{array}$ & $\begin{array}{c}\text { Non-addicted } \\
\text { males, } M(S D) \\
\text { Mężczyźni } \\
\text { nieuzależnieni, } \\
M(S D)\end{array}$ & $\begin{array}{c}\text { Interaction } \\
\text { group } \times \text { sex, } \\
F(1,241) \\
\text { Interakcja } \\
\text { grupa } \times \text { płeć, } \\
\mathrm{F}(1,241)\end{array}$ & $p$ & $\eta^{2}$ \\
\hline \multicolumn{8}{|c|}{$\begin{array}{l}\text { Retrospectively assessed mother's attitudes } \\
\text { Retrospektywna ocena postaw matki }\end{array}$} \\
\hline $\begin{array}{l}\text { Acceptance/Rejection } \\
\text { Akceptacja/Odrzucenie }\end{array}$ & $38.00(9.82)$ & 37.32 (11.39) & $40.42(9.13)$ & 39.44 (7.95) & 0.40 & 0.526 & - \\
\hline $\begin{array}{l}\text { Demanding } \\
\text { Wymaganie }\end{array}$ & $28.17(10.35)$ & 26.94 (11.13) & 27.59 (9.49) & $25.24(8.90)$ & 1.72 & 0.190 & - \\
\hline $\begin{array}{l}\text { Autonomy } \\
\text { Autonomia }\end{array}$ & $35.72(8.18)$ & $35.40(8.97)$ & $37.23(7.67)$ & $38.10(6.80)$ & 0.06 & 0.797 & - \\
\hline $\begin{array}{l}\text { Inconsequence } \\
\text { Niekonsekwencja }\end{array}$ & $25.05(9.86)$ & $22.30(11.32)$ & $23.50(9.90)$ & $21.65(9.22)$ & 2.75 & 0.098 & - \\
\hline $\begin{array}{l}\text { Protectiveness } \\
\text { Ochranianie }\end{array}$ & $34.47(9.45)$ & $31.89(8.92)$ & $36.76(8.20)$ & $33.30(8.03)$ & 6.48 & 0.011 & 0.03 \\
\hline \multicolumn{8}{|c|}{$\begin{array}{l}\text { Retrospectively assessed father's attitudes } \\
\text { Retrospektywna ocena postaw ojca }\end{array}$} \\
\hline $\begin{array}{l}\text { Acceptance/Rejection } \\
\text { Akceptacja/Odrzucenie }\end{array}$ & $33.08(12.88)$ & $38.30(10.65)$ & $34.47(9.12)$ & $36.72(9.81)$ & 6.67 & 0.010 & 0.03 \\
\hline $\begin{array}{l}\text { Demanding } \\
\text { Wymaganie }\end{array}$ & $28.36(10.13)$ & $24.00(10.54)$ & $29.90(9.29)$ & 26.46 (8.72) & 8.60 & 0.004 & 0.04 \\
\hline $\begin{array}{l}\text { Autonomy } \\
\text { Autonomia }\end{array}$ & $34.11(9.75)$ & $37.89(8.60)$ & $34.15(8.90)$ & $36.67(7.63)$ & 6.79 & 0.010 & 0.03 \\
\hline $\begin{array}{l}\text { Inconsequence } \\
\text { Niekonsekwencja }\end{array}$ & $28.05(11.20)$ & $23.00(9.14)$ & 27.25 (9.79) & $23.89(8.67)$ & 9.75 & 0.002 & 0.04 \\
\hline $\begin{array}{l}\text { Protectiveness } \\
\text { Ochranianie }\end{array}$ & $29.00(8.68)$ & $29.03(9.18)$ & $29.27(7.67)$ & $28.23(6.28)$ & 0.22 & 0.640 & - \\
\hline
\end{tabular}

Tab. 3. Results of two-factor variance analysis for interactions of factors "group" (addicted to alcohol/non-addicted) and "sex" (females/males) for variables "retrospectively assessed mother's attitudes" and "retrospectively assessed father's attitudes" (study 1)

Tab. 3. Wyniki dwuczynnikowej analizy wariancji dla interakcji czynników "grupa” (uzależnieni od alkoholu/nieuzależnieni) i "płeć" (kobiety/mężczyźni) dla zmiennych „retrospektywna ocena postaw matki” i „retrospektywna ocena postaw ojca” (badanie 1)

\section{Research tools}

In the research the author used Mieczysław Plopa's Questionnaire of Retrospective Assessment of Parental Attitudes (KPR-Roc) (2005) comprising of two versions, used for retrospective assessment of mother's and father's attitudes, which is performed by an adult child. Each version includes 50 statements rated on a 5-point scale. KPR-Roc is based on the following dimensions:

- Acceptance/Rejection. Acceptance: the respondent remembers the parent as accepting them unconditionally, displaying open, spontaneous behaviours, giving support. Rejection: the person feels that they were not accepted by the parent, remember emotional distance and cold relationships, more instrumental than subjective.

- Demanding. Excessively demanding attitude: the respondent remembers the parent as demanding unconditional obedience, not tolerating resistance. The person expresses a belief that the parent acted inadequately, was cold, difficult to maintain contact with.

- Autonomy. The attitude of autonomy: the respondent remembers the parent as allowing for solving problems in- poczucie wsparcia. Odrzucenie: osoba odczuwa, że nie była akceptowana przez rodzica, pamięta dystans emocjonalny i chłodne relacje, bardziej instrumentalne niż podmiotowe.

- Wymaganie. Postawa nadmiernie wymagająca: badany pamięta rodzica jako wymagającego bezwzględnego posłuszeństwa, nietolerującego sprzeciwu. Wyraża przekonanie, że rodzic działał nieadekwatnie, był chłodny, trudny w kontakcie.

- Autonomia. Postawa autonomii: osoba pamięta rodzica jako pozwalającego na samodzielne rozwiązywanie problemów, podejmowanie decyzji. Rodzic jest zapamiętany jako elastyczny, otwarty na udzielanie wsparcia i nienarzucający swojego zdania.

- Niekonsekwencja. Postawa niekonsekwentna: badany pamięta rodzica jako osobę zmienną, nastrojową, nerwową, niekonsekwentną w wyrażaniu opinii i uczuć czy podejmowaniu decyzji.

- Ochranianie. Postawa nadmiernie ochraniająca: osoba pamięta rodzica jako nadmiernie ingerującego w jej osobiste problemy, przejawiającego przesadną troskę o przyszłość dziecka i przeszkadzającego mu w budowaniu własnej tożsamości. 
dependently, making decisions. The parent is remembered as flexible, open for providing support and not imposing their opinions.

- Inconsequence. An inconsequent attitude: the respondent remembers the parent as a person who was labile, moody, nervous, inconsequent regarding the expression of opinions or feelings or in terms of decision making.

- Protectiveness. Excessively protective attitude: the person remembers the parent as overly interfering in their personal problems, displaying exaggerated care about the child's future and disturbing them in building their own identity.

The exact value of the Cronbach's alpha for particular dimensions in the author's own research was equal to $0.75-0.89$ in KPR-Roc Mother and 0.76-0.91 in KPR-Roc Father. The sociodemographic data were collected by means of a personal questionnaire (author's own work).

\section{RESULTS}

\section{Retrospectively assessed parental attitudes in the group of the alcohol-dependent and the non-dependent (study 1)}

In order to verify the hypotheses concerning the differences in terms of retrospectively assessed parental attitudes between the alcohol-dependent and the non-dependent two-way analysis of variance was used, the results of which regarding the interaction between two factors: addiction (addiction/lack of addiction) and sex (female/male) are presented in the tab. 3 .

In the case of retrospectively assessed mother's attitude only for variable Protectiveness a differentiation occurred between the alcohol-dependent group and non-dependent one. The post hoc analysis conducted by the means of Tukey's test proved that this effect concerns only alcoholdependent men who score significantly higher than nondependent men $(F=6.99 ; p=0.009)$ and non-dependent women $(F=8.52 ; p=0.004)$.

As far as the retrospectively assessed father's attitude is concerned, the alcohol-dependent differ, in line with the hypothesis, from the non-dependent on four scales (Acceptance/Rejection, Demanding, Autonomy, Inconsequence). Detailed post hoc analysis proved that in the case of: (1) variable Acceptance/Rejection - only alcohol-dependent females scored lower than the non-dependent $(F=4.72$; $p=0.031)$, (2) variable Demanding - alcohol-dependent females scored higher than the non-dependent $(F=3.89$; $p=0.050)$, whereas alcohol-dependent males scored higher than the non-dependent males $(F=5.39 ; p=0.021)$ or non-dependent females $(F=9.93$; $p=0.002)$, (3) variable Autonomy - only alcohol-dependent males scored lower than non-dependent females ( $F=4.84 ; p=0.029)$, (4) variable Inconsequence - alcohol-dependent females scored higher than non-dependent females $(F=5.11 ; p=0.025)$ or non-dependent males $(F=4.74 ; p=0.030)$, whereas
Współczynnik rzetelności alfa Cronbacha dla poszczególnych wymiarów w badaniach własnych wyniósł $0,75-0,89$ w KPR-Roc Matka oraz 0,76-0,91 w KPR-Roc Ojciec. Informacje socjodemograficzne zbierano za pomocą kwestionariusza osobowego własnego autorstwa.

\section{WYNIKI}

\section{Retrospektywna ocena postaw rodziców u osób uzależnionych i nieuzależnionych od alkoholu (badanie 1)}

W celu weryfikacji hipotez dotyczących występowania różnic w zakresie retrospektywnej oceny postaw rodziców między osobami uzależnionymi od alkoholu a nieuzależnionymi przeprowadzono dwuczynnikową analizę wariancji, której wyniki dla interakcji dwóch czynników: uzależnienie (uzależnienie/brak uzależnienia) i płeć (kobieta/mężczyzna) prezentuje tab. 3.

W przypadku retrospektywnej oceny postawy matki jedynie w zakresie zmiennej Ochranianie wystąpiło zróżnicowanie między osobami uzależnionymi a nieuzależnionymi. Analiza post hoc dokonana za pomocą testu Tukeya wykazała, iż efekt ten dotyczy jedynie mężczyzn uzależnionych od alkoholu, którzy uzyskują istotnie wyższe wyniki niż mężczyźni nieuzależnieni $(F=6,99 ; p=0,009)$ i kobiety nieuzależnione $(F=8,52 ; p=0,004)$.

Jeśli chodzi o retrospektywną ocenę postawy ojca, osoby uzależnione od alkoholu różnią się, zgodnie z hipotezami, od osób nieuzależnionych na czterech skalach (Akceptacja/Odrzucenie, Wymaganie, Autonomia, Niekonsekwencja). Szczegółowa analiza post hoc wykazała, iż w przypadku: (1) zmiennej Akceptacja/Odrzucenie - tylko kobiety uzależnione uzyskują wyniki niższe niż kobiety nieuzależnione $(F=4,72 ; p=0,031)$, (2) zmiennej Wymaganie - kobiety uzależnione osiągają wyższe wyniki niż kobiety nieuzależnione $(F=3,89 ; p=0,050)$, a mężczyźni uzależnieni mają wyższe wyniki niż mężczyźni nieuzależnieni $(F=5,39 ; p=0,021)$ i kobiety nieuzależnione $(F=9,93 ; p=0,002),(3)$ zmiennej Autonomia - jedynie mężczyźni uzależnieni osiągają niższe wyniki niż kobiety nieuzależnione $(F=4,84 ; p=0,029)$, (4) zmiennej Niekonsekwencja - kobiety uzależnione uzyskują wyższe wyniki niż kobiety nieuzależnione $(F=5,11 ; p=0,025)$ i mężczyźni nieuzależnieni $(F=4,74 ; p=0,030)$, a mężczyźni uzależnieni mają wyższe wyniki niż kobiety nieuzależnione $(F=5,02 ; p=0,026)$ i mężczyźni nieuzależnieni $(F=5,00 ; p=0,026)$.

\section{Retrospektywna ocena postaw rodziców u osób uzależnionych od alkoholu w zależności od występowania uzależnienia u rodziców (badanie 2)}

Badanie 2 koncentrowało się na analizie ewentualnych różnic wśród kobiet i mężczyzn uzależnionych od alkoholu w zależności od występowania uzależnienia w rodzinie pochodzenia. Do testowania różnic posłużył test nieparametryczny $U$ Manna-Whitneya (tab. 4, 5). 


\begin{tabular}{|c|c|c|c|c|c|c|}
\hline $\begin{array}{l}\text { Variable } \\
\text { Zmienna }\end{array}$ & $\begin{array}{l}\text { Addicted females with the addic- } \\
\text { tion in the family }(n=31), M(S D) \\
\text { Kobiety uzależnione z uzależnieniem } \\
\quad \text { w rodzinie }(\mathrm{n}=31), M(S D)\end{array}$ & $\begin{array}{c}\text { Addicted females with no addiction } \\
\text { in the family }(\boldsymbol{n}=24), M(S D) \\
\text { Kobiety uzależnione bez uzależnienia } \\
\text { wrodzinie }(\mathrm{n}=24), M(\mathrm{SD})\end{array}$ & $\boldsymbol{U}$ & $Z$ & $p$ & $r_{g}$ \\
\hline \multicolumn{7}{|c|}{$\begin{array}{l}\text { Retrospectively assessed mother's attitudes } \\
\text { Retrospektywna ocena postaw matki }\end{array}$} \\
\hline $\begin{array}{l}\text { Acceptance/Rejection } \\
\text { Akceptacja/Odrzucenie }\end{array}$ & $34.07(8.11)$ & $40.39(10.23)$ & 185.50 & 2.72 & 0.007 & 0.44 \\
\hline \begin{tabular}{|l|} 
Demanding \\
Wymaganie \\
\end{tabular} & $29.93(9.21)$ & $27.56(11.16)$ & 289.50 & -0.80 & 0.423 & - \\
\hline $\begin{array}{l}\text { Autonomy } \\
\text { Autonomia } \\
\end{array}$ & $34.41(7.34)$ & $36.91(8.76)$ & 258.50 & 1.37 & 0.170 & - \\
\hline \begin{tabular}{|l|} 
Inconsequence \\
Niekonsekwencja
\end{tabular} & $27.86(9.31)$ & $24.39(10.89)$ & 271.00 & -1.14 & 0.253 & - \\
\hline $\begin{array}{l}\text { Protectiveness } \\
\text { Ochranianie }\end{array}$ & $33.10(9.78)$ & $36.26(8.30)$ & 270.00 & 1.16 & 0.246 & - \\
\hline \multicolumn{7}{|c|}{$\begin{array}{l}\text { Retrospectively assessed father's attitudes } \\
\text { Retrospektywna ocena postaw ojca } \\
\end{array}$} \\
\hline $\begin{array}{l}\text { Acceptance/Rejection } \\
\text { Akceptacja/Odrzucenie }\end{array}$ & $30.83(11.66)$ & $38.43(11.85)$ & 203.00 & 2.39 & 0.017 & 0.39 \\
\hline \begin{tabular}{|l|} 
Demanding \\
Wymaganie \\
\end{tabular} & $28.86(8.54)$ & $27.52(10.62)$ & 317.50 & -0.29 & 0.775 & - \\
\hline $\begin{array}{l}\text { Autonomy } \\
\text { Autonomia }\end{array}$ & $30.65(8.38)$ & $38.35(8.77)$ & 177.50 & 2.86 & 0.004 & 0.47 \\
\hline \begin{tabular}{|l|} 
Inconsequence \\
Niekonsekwencja
\end{tabular} & $29.34(8.79)$ & $26.61(11.58)$ & 284.00 & -0.90 & 0.367 & - \\
\hline $\begin{array}{l}\text { Protectiveness } \\
\text { Ochranianie }\end{array}$ & $26.93(7.60)$ & $32.48(8.38)$ & 201.50 & 2.42 & 0.015 & 0.43 \\
\hline \multicolumn{7}{|c|}{$\begin{array}{l}\text { M - mean; } \boldsymbol{n} \text { - number of people in the subgroups; } \boldsymbol{p} \text { - statistical significance level; } \boldsymbol{r}_{g} \text { - Glass's two-serial correlation coefficient for defining the size of the effect; } \\
\text { SD - standard deviation; } \boldsymbol{U}, \mathbf{Z} \text { - U Mann-Whitney's test value. } \\
\mathbf{M} \text { - średnia; } \mathbf{n} \text { - liczba osób w podgrupach; } \mathbf{p} \text { - poziom istotności statystycznej; } \boldsymbol{r}_{\mathbf{g}} \text { - wspótczynnik korelacji dwuseryjnej Glassa dla okréslenia wielkości efektu; } \\
\text { SD - odchylenie standardowe; } \mathbf{U}, \mathbf{Z} \text { - wartości testu U Manna-Whitneya. }\end{array}$} \\
\hline
\end{tabular}

Tab. 4. U Mann-Whitney's test for testing differences in terms of retrospectively assessed mother's and father's attitudes in the group of alcohol-dependent females regarding the occurrence of alcohol addiction in the family history (study 2)

Tab. 4. Test U Manna-Whitneya dla testowania różnic w zakresie retrospektywnej oceny postaw matki i ojca w grupie kobiet uzależnionych od alkoholu w zależności od występowania uzależnienia od alkoholu w rodzinie pochodzenia (badanie 2)

alcohol-dependent males scored higher than non-dependent females $(F=5.02 ; p=0.026)$ or non-dependent males $(F=5.00 ; p=0.026)$.

\section{Retrospectively assessed parental attitudes among the alcohol-dependent regarding the occurrence of parents' addiction (study 2)}

Study 2 concerned the analysis of presumptive differences among alcohol-dependent females and males regarding the occurrence of addiction in the family history. With the aim of testing the difference a non-parametric U Mann-Whitney's test was used (tabs. 4, 5).

As the results suggest (tab. 4) alcohol-dependent females with a family history of alcohol addiction differ from non-dependent females with no family history of alcohol addiction and scored: in line with the hypotheses (1) lower for variable Mother Acceptance/Rejection, (2) lower for variable Father Acceptance/Rejection, (3) lower for variable Father Autonomy and, against the assumed hypothesis, (4) lower for variable Father Protec-
Jak wskazują wyniki (tab. 4), kobiety uzależnione od alkoholu, w których rodzinie pochodzenia występowało uzależnienie od alkoholu, różnią się od kobiet uzależnionych, u których ono nie występowało, i osiągają: zgodnie z hipotezami (1) niższe wyniki w zakresie zmiennej Matka Akceptacja/Odrzucenie, (2) niższe wyniki w zakresie zmiennej Ojciec Akceptacja/Odrzucenie, (3) niższe wyniki w zakresie zmiennej Ojciec Autonomia oraz wbrew zakładanej hipotezie (4) niższe wyniki w zakresie zmiennej Ojciec Ochranianie. Mężczyźni uzależnieni od alkoholu, w których rodzinie pochodzenia występowało uzależnienie od alkoholu, różnią się zgodnie z hipotezami - od mężczyzn uzależnionych, u których ono nie występowało (tab. 5), i uzyskują: (1) niższe wyniki w zakresie zmiennej Ojciec Akceptacja/Odrzucenie, (2) wyższe wyniki w zakresie zmiennej Ojciec Wymaganie, (3) wyższe wyniki w zakresie Ojciec Niekonsekwencja.

\section{OMÓWIENIE}

Niniejszy artykuł ma na celu prezentację badań nad retrospektywną oceną postaw rodzica w grupach osób uzależnionych i nieuzależnionych od alkoholu (badanie 1) oraz 


\begin{tabular}{|c|c|c|c|c|c|c|}
\hline $\begin{array}{l}\text { Variable } \\
\text { Zmienna }\end{array}$ & \begin{tabular}{|}
$\begin{array}{c}\text { Addicted males with the ad- } \\
\text { diction in the family }(\boldsymbol{n}=\mathbf{5 6}), \\
M(S D) \\
\text { Mężczyźni uzależnieni } \\
\text { z uzależnieniem w rodzinie }(\mathrm{n}=56), \\
M(S D)\end{array}$ \\
\end{tabular} & $\begin{array}{l}\text { Addicted males with no addic- } \\
\text { tion in the family }(\boldsymbol{n}=110) \text {, } \\
\qquad M(S D) \\
\text { Mężczyźni uzależnieni bez } \\
\text { uzależnienia w rodzinie }(\mathrm{n}=110) \text {, } \\
\text { M(SD) }\end{array}$ & $\boldsymbol{U}$ & $Z$ & $p$ & $r_{g}$ \\
\hline \multicolumn{7}{|c|}{$\begin{array}{l}\text { Retrospectively assessed mother's attitudes } \\
\text { Retrospektywna ocena postaw matki }\end{array}$} \\
\hline $\begin{array}{l}\text { Acceptance/Rejection } \\
\text { Akceptacja/Odrzucenie }\end{array}$ & $39.13(10.90)$ & $40.70(7.99)$ & $2,719.00$ & 0.13 & 0.893 & - \\
\hline \begin{tabular}{|l} 
Demanding \\
Wymaganie
\end{tabular} & $29.08(10.44)$ & $28.64(9.13)$ & $2,661.00$ & -0.35 & 0.727 & - \\
\hline \begin{tabular}{|l|} 
Autonomy \\
Autonomia \\
\end{tabular} & $35.63(9.71)$ & $37.36(7.38)$ & $2,529.00$ & 0.84 & 0.402 & - \\
\hline \begin{tabular}{|l|} 
Inconsequence \\
Niekonsekwencja
\end{tabular} & $25.10(10.29)$ & 24.37 (9.28) & $2,668.50$ & -0.32 & 0.747 & - \\
\hline $\begin{array}{l}\text { Protectiveness } \\
\text { Ochranianie }\end{array}$ & $35.21(10.41)$ & $37.25(7.05)$ & $2,566.50$ & 0.70 & 0.484 & - \\
\hline \multicolumn{7}{|c|}{$\begin{array}{l}\text { Retrospectively assessed father's attitudes } \\
\text { Retrospektywna ocena postaw ojca }\end{array}$} \\
\hline \begin{tabular}{|l|} 
Acceptance/Rejection \\
Akceptacja/Odrzucenie
\end{tabular} & $32.33(10.06)$ & 35.94 (8.79) & $1,947.50$ & 2.17 & 0.030 & 0.22 \\
\hline $\begin{array}{l}\text { Demanding } \\
\text { Wymaganie }\end{array}$ & $32.94(8.30)$ & $29.84(8.59)$ & $1,979.00$ & -2.05 & 0.041 & -0.21 \\
\hline \begin{tabular}{|l|} 
Autonomy \\
Autonomia \\
\end{tabular} & $32.67(9.36)$ & $35.13(8.20)$ & $2,090.00$ & 1.61 & 0.108 & - \\
\hline \begin{tabular}{|l|} 
Inconsequence \\
Niekonsekwencja \\
\end{tabular} & $30.69(9.64)$ & $26.45(9.39)$ & $1,887.00$ & -2.41 & 0.016 & -0.24 \\
\hline $\begin{array}{l}\text { Protectiveness } \\
\text { Ochranianie }\end{array}$ & $29.44(8.57)$ & $30.28(7.85)$ & $2,360.50$ & 0.53 & 0.593 & - \\
\hline \multicolumn{7}{|c|}{$\begin{array}{l}\text { M - mean; } \boldsymbol{n} \text { - number of people in the subgroups; } \boldsymbol{p} \text { - statistical significance level; } \boldsymbol{r}_{g} \text { - Glass's two-serial correlation coefficient for defining the size of the effect; } \\
\text { SD - standard deviation; } \boldsymbol{U}, \mathbf{Z} \text { - U Mann-Whitney's test value. } \\
\text { M -średnia; } \mathbf{n} \text { - liczba osób w podgrupach; } \mathbf{p} \text { - poziom istotności statystycznej; } \boldsymbol{r}_{\mathbf{g}} \text { - współczynnik korelacji dwuseryjnej Glassa dla określenia wielkości efektu; SD - odchylenie } \\
\text { standardowe; } \mathbf{U , Z} \mathbf{Z} \text { - wartości testu U Manna-Whitneya. }\end{array}$} \\
\hline
\end{tabular}

Tab. 5. U Mann-Whitney's test for testing differences in terms of retrospectively assessed mother's and father's attitudes in the group of alcohol-dependent males regarding the occurrence of alcohol addiction in the family history (study 2)

Tab. 5. Test U Manna-Whitneya dla testowania różnic $w$ zakresie retrospektywnej oceny postaw matki i ojca w grupie mężczyzn uzależnionych od alkoholu $w$ zależności od występowania uzależnienia od alkoholu $w$ rodzinie pochodzenia (badanie 2)

Alcohol-dependent males with a family history of alcohol addiction differ - in line with the hypotheses - from alcohol-dependent males with no family history of alcohol addiction (tab. 5) and scored: (1) lower for variable Father Acceptance/Rejection, (2) higher for variable Father Demanding, (3) higher for variable Father Inconsequence.

\section{DISCUSSION}

The aim of this article is to present the study results on retrospectively assessed parental attitudes in the group of individuals with alcohol dependence as well as in the group of individuals without addiction to alcohol (study 1) and in the group of alcohol-dependent individuals regarding the occurrence of the addiction in the family history (study 2). There have been many studies concerning the non-dependent people's perception of their own parents, also children's or adults' who grew up in houses, where the problem of addiction was present, but there have been few reports concerning the individuals with alcohol dependence. It seems w grupie osób uzależnionych w zależności od występowania uzależnienia w rodzinie pochodzenia (badanie 2). Wiele jest badań dotyczących percepcji własnych rodziców wśród osób nieuzależnionych, również dzieci czy dorosłych pochodzących z domów, w których obecny był problem uzależnienia, lecz niewiele takich prac dotyczy osób uzależnionych. Wydaje się, że pogłębianie wiedzy z tego zakresu ma ważne uzasadnienie zarówno teoretyczne, jak i praktyczne. Z jednej strony pozwala poszerzyć obraz kliniczny osoby uzależnionej od alkoholu o te aspekty funkcjonowania intrapsychicznego, które w szerokim rozumieniu mogą mieć związek z samym uzależnieniem, obrazem siebie czy obrazem drugiego człowieka, a także - w myśleniu systemowym - obrazem rodziny i siebie w roli rodzica. $Z$ drugiej strony tak pogłębiony obraz kliniczny może wyznaczać kierunki bardziej zaawansowanej pracy terapeutycznej z osobami uzależnionymi, w tym pracy nad obrazem siebie jako rodzica.

Różnice między osobami uzależnionymi od alkoholu a nieuzależnionymi zaobserwowane w badaniu 1 w odniesieniu do retrospektywnej oceny postaw matki i ojca wydają się złożone. 
that deepening the knowledge in this area has an important justification both theoretically and practically. On the one hand, it extends the clinical image of an alcohol-dependent individual by these aspects of intrapsychic functioning, which in general can be connected with the addiction itself, self-image or image of others - but also in the systemic approach - the image of the family and oneself as a parent. On the other hand, such a complex clinical image may determine directions regarding more advanced therapeutic work with the alcohol-dependent individuals, including the work on one's own image as a parent.

The complex differences between the alcohol-dependent and non-dependent individuals have been pointed out in study 1 with regards to the retrospectively assessed mother's and father's attitudes.

In the retrospectively assessed mother's attitudes only alcohol-dependent males scored higher regarding Protectiveness than non-dependent males or females. There was no difference between the alcohol-dependent and the nondependent in terms of maternal acceptance/rejection, demanding, autonomy and inconsequence. Featured results are partially concurrent with the results accessible in the literature, in line with which, the perception of the mothers as excessively protective is connected with an increase of problem drinking among young males (Patock-Peckham and Morgan-Lopez, 2010). Whereas other studies point out that the quality of mother-adolescent relationship is not a factor reinforcing or mediating for using psychoactive substances among adolescents regardless of the sex (Branstetter et al., 2009). What is more, according to studies in which the individuals with alcohol dependence took part, it was concluded that the parenting style, especially mother's, plays a minor role in the context of perception of self than in the non-clinical group, whereas mothers are generally remembered as emotionally warmer than fathers (De Jong and Jacobs, 2010). Taking into account the distinct prevalence of individuals with an alcohol-dependent father (in comparison with the people having both parents addicted) in study 1, it seems that the lack of differences in the retrospectively assessed mother's attitude among alcohol-dependent women in comparison with non-dependent women and in the majority of dimensions regarding alcohol-dependent males in comparison with non-dependent males, supports well-known in the literature thesis about a possible protective role of the mother in a family with an alcohol-dependent father (Cierpiałkowska and Grzegorzewska, 2016; Gąsior, 2012). The present research shows that the parenting attitude of the mother is assessed as relatively optimal and similar to the one revealed by the mothers in families with no addiction to alcohol. It appears that the perceived difference between alcohol-dependent and non-dependent males and females in terms of Protecting (addicted males assess their mothers as more protective) may result from exaggerated caring about the sons by the mothers and controlling in the situation when the father is alcohol-dependent - perhaps in order to protect
W retrospektywnej ocenie postaw matki jedynie mężczyźni uzależnieni od alkoholu uzyskują wyższe wyniki od mężczyzn i kobiet nieuzależnionych w zakresie Ochraniania. Nie odnotowano różnic między osobami uzależnionymi i nieuzależnionymi w zakresie matczynej akceptacji/ odrzucenia, wymagania, autonomii i niekonsekwencji. Prezentowane wyniki są częściowo zbieżne $\mathrm{z}$ wynikami dostępnymi w literaturze, zgodnie z którymi postrzeganie matek jako nadmiernie chroniących i nadopiekuńczych wiąże się ze wzrostem problemowego picia u młodych mężczyzn (Patock-Peckham i Morgan-Lopez, 2010). Inne badania wskazują jednak, że jakość relacji matka-adolescent nie jest czynnikiem zwiększającym czy mediującym używanie substancji psychoaktywnej u adolescentów niezależnie od płci (Branstetter et al., 2009). Ponadto w badaniach z udziałem osób uzależnionych uznano, iż styl wychowania rodziców, zwłaszcza matki, odgrywa mniejszą rolę w kontekście percepcji siebie niż w grupie nieklinicznej, a matki generalnie wspominane są jako emocjonalnie cieplejsze niż ojcowie (De Jong i Jacobs, 2010). Biorąc pod uwagę zdecydowaną przewagę $\mathrm{w}$ badaniu 1 osób $\mathrm{z}$ uzależnionym ojcem (w stosunku do osób z uzależnieniem obojga rodziców), wydaje się, że brak różnic w retrospektywnej ocenie matki u kobiet uzależnionych $\mathrm{w}$ porównaniu $\mathrm{z}$ kobietami nieuzależnionymi i w przeważającej części wymiarów u mężczyzn uzależnionych $\mathrm{w}$ porównaniu z mężczyznami nieuzależnionymi wspiera znaną $\mathrm{w}$ literaturze tezę o możliwej ochronnej roli matki $\mathrm{w}$ rodzinie $\mathrm{z}$ uzależnionym ojcem (Cierpiałkowska i Grzegorzewska, 2016; Gąsior, 2012). Niniejsze badania wskazują, że postawa rodzicielska matki oceniana jest jako względnie optymalna i podobna do postaw matek $\mathrm{w}$ rodzinach bez uzależnienia od alkoholu. Wydaje się także, iż zaobserwowana różnica między mężczyznami uzależnionymi a mężczyznami i kobietami nieuzależnionymi w wymiarze Ochraniania (uzależnieni mężczyźni oceniają swoje matki jako bardziej ochraniające) może wynikać $z$ otaczania synów przez matki nadmierną troską i kontrolą w sytuacji uzależnienia ojca - być może w celu ochronienia chłopców przed modelującym spożywanie alkoholu ojcem.

W przypadku retrospektywnej oceny postaw ojca wszystkie dostrzeżone różnice między osobami uzależnionymi i nieuzależnionymi są zgodne $\mathrm{z}$ kierunkiem zarysowanym w hipotezach.

Odnosząc się do oceny postawy ojca wśród mężczyzn uzależnionych od alkoholu, należy stwierdzić, że uzyskują oni wyższe wyniki od mężczyzn i kobiet nieuzależnionych w zakresie Wymagania i Niekonsekwencji oraz niższe w zakresie autonomii w porównaniu z kobietami nieuzależnionymi. Mają zatem tendencję do postrzegania ojców jako nakazujących, chłodnych i trudnych w kontakcie, jak również zmiennych i niekonsekwentnych w wyrażaniu opinii i uczuć oraz podejmowaniu decyzji. Znajduje to potwierdzenie w literaturze, w której zwraca się uwagę na to, iż percepcja ojca jako despotycznego, pobłażliwego lub chłodnego wiąże się ze wzrostem problemowego używania alkoholu, 
In the case of retrospectively assessed the father's attitudes all discerned differences between the alcohol-dependent and the non-dependent are in accordance with the postulated hypotheses.

Regarding the assessment of father's attitude among alcohol-dependent males, there is a need to state that they scored higher in terms of Demanding and Inconsequence than non-dependent males and females and lower concerning autonomy in comparison with non-dependent females. Therefore they have a tendency to perceive the fathers as bossy, distant and difficult to have contact with, as well as labile and inconsequent in terms of expressing opinions or feelings or making decisions. This issue has been confirmed in the literature, where it is emphasised that the perception of the father as despotic, permissive or distant is connected with the increase of problematic alcohol drinking, in which various mediating factors take part: a higher level of depressiveness and antisociality or a lower level of self-esteem (Patock-Peckham and Morgan-Lopez, 2009; Patock-Peckham et al., 2001).

Females with alcohol dependence who assess the father's attitudes scored higher than non-dependent females or males in terms of inconsequence and - in comparison with nondependent females - lower regarding acceptance/rejection and higher concerning demanding, which means that they can perceive the fathers as labile and bossy, but also distant, deprived of warmth and not accepting. It is compatible with other studies which point out that the fathers are perceived by the addicted individuals as rejecting (De Jong and Jacobs, 2010). Moreover, the feeling of disregard, rejection by the father and a lack of warmth from his side as well as experiencing oneself as unwanted can have an impact on the increase of alcohol consumption among students by escalating the level of depressiveness and stress or weakening the ability to self-regulate (Patock-Peckham and MorganLopez, 2007, 2009; Patock-Peckham et al., 2001).

In study 2 the attention was drawn to the differences in retrospectively assessed parental attitudes among the alcoholdependent individuals regarding the occurrence of the addiction to alcohol in the family history.

The hypotheses relating to the differences in the retrospectively assessed mother's attitudes were not confirmed - except for the assessment of acceptance/rejection conducted by the females. The alcohol-dependent women with a family history of alcohol addiction, in accordance with the hypothesis, tended to assess the mothers as more rejecting than women with no family history of alcohol addiction.

The hypotheses regarding the differences in the retrospectively assessed father's attitudes were partially confirmed. The group consisting of alcohol-dependent females and males assessed the father's attitude - in line with the hypothesis - as more rejecting. Additionally, the females with a family history of alcohol addiction assessed the father as less supportive regarding their autonomy and - discrepantly with the hypothesis - as less interferential in their matters; the hypotheses regarding the assessment of the father w czym uczestniczą różne czynniki mediujące: wyższy poziom depresyjności i antyspołeczności czy niższe poczucie własnej wartości (Patock-Peckham i Morgan-Lopez, 2009; Patock-Peckham et al., 2001).

Kobiety uzależnione od alkoholu oceniające postawy ojca uzyskują wyższe wyniki od kobiet i mężczyzn nieuzależnionych w zakresie niekonsekwencji oraz - w porównaniu z kobietami nieuzależnionymi - niższe w zakresie akceptacji/odrzucenia i wyższe w zakresie wymagania, co oznacza, że mogą postrzegać ojców jako zmiennych i nakazujących, a także zdystansowanych, pozbawionych ciepła i nieakceptujących. Jest to zgodne z innymi badaniami, wskazującymi, iż ojcowie spostrzegani są przez osoby uzależnione jako odrzucający (De Jong i Jacobs, 2010). Ponadto poczucie lekceważenia, odrzucenia przez ojca i braku ciepła z jego strony oraz przeżywanie siebie jako niechcianego mogą wpływać na wzrost spożycia alkoholu u studentów przez podniesienie poziomu depresyjności i stresu czy osłabienie zdolności do samoregulacji (Patock-Peckham i Morgan-Lopez, 2007, 2009; Patock-Peckham et al., 2001).

W badaniu 2 uwagę poświęcono różnicom w retrospektywnej ocenie postaw rodziców między osobami uzależnionymi w zależności od występowania uzależnienia od alkoholu w rodzinie pochodzenia.

Hipotezy odnoszące się do różnic w retrospektywnej ocenie postaw matki nie zostały potwierdzone - $\mathrm{z}$ wyjątkiem oceny pod względem akceptacji/odrzucenia dokonywanej przez kobiety. Kobiety uzależnione, w których rodzinach pochodzenia obecne było uzależnienie od alkoholu, zgodnie $z$ hipotezą oceniły matki jako bardziej odrzucające niż kobiety bez uzależnienia $\mathrm{w}$ rodzinie pochodzenia.

Z kolei hipotezy dotyczące różnic w retrospektywnej ocenie postaw ojca zostały potwierdzone częściowo. Grupa kobiet i mężczyzn uzależnionych, w których rodzinie pochodzenia występowało uzależnienie, oceniła postawę ojca - zgodnie z hipotezą - jako bardziej odrzucającą. Dodatkowo kobiety $\mathrm{z}$ uzależnieniem $\mathrm{w}$ rodzinie pochodzenia oceniły ojca jako mniej wspierającego ich autonomię $\mathrm{i}$ - niezgodnie $\mathrm{z}$ hipotezą mniej ingerującego w ich sprawy; nie potwierdzono hipotez odnoszących się do oceny ojca jako bardziej wymagającego i niekonsekwentnego. Mężczyźni z uzależnieniem w rodzinie pochodzenia retrospektywnie postrzegają ojca - zgodnie z hipotezami - jako bardziej wymagającego i niekonsekwentnego. Nie potwierdzono natomiast hipotez odnośnie do wymiarów autonomii i ochraniania.

Wyłaniające się z powyższego opisu obrazy matki i ojca w retrospektywnej ocenie osób uzależnionych w zależności od występowania uzależnienia w rodzinie pochodzenia są niejednoznaczne. Pod względem oceny matki w większości wymiarów nie zaobserwowano różnic między grupami, jedynie kobiety uzależnione $\mathrm{z}$ historią uzależnienia $\mathrm{w}$ rodzinie oceniły matki jako mniej akceptujące. W retrospektywnej ocenie ojca u osób uzależnionych z uzależnieniem $\mathrm{w}$ rodzinie pochodzenia zarysowują się pewne tendencje do postrzegania go jako mniej akceptującego i, w zależności od płci badanych, bardziej wymagającego, niekonsekwentnego 
as being more demanding and inconsequent have not been confirmed. The males with a family history of alcohol addiction retrospectively perceived the father - in accordance with the hypotheses - as more demanding and inconsequent. However, the hypotheses concerning the dimensions of autonomy and protectiveness have not been confirmed. The images of mother and father in a retrospective assessment of the alcohol-dependent emerging from the above description depending on the occurrence of addiction in the family history are ambiguous. In terms of assessment of the mother, in the majority of dimensions there were no significant differences between the groups, only the alcohol-dependent females with a family history of alcohol addiction assessed mothers as less accepting. In the retrospective assessment of the father among the alcohol-dependent individuals with a family history of alcohol addiction there are some tendencies to perceive him as less accepting and, depending on the sex of the respondents, more demanding, inconsequent and impeding autonomy. Since the addiction in the family concerned in this study mostly fathers, it seems that their drinking alcohol is reflected in the adult children's assessment, although - what is interesting - these are the assessments which differ depending on the sex. According to the data deriving from literature, the father's addiction is entwined with lower parental sensitivity, lower engagement or higher level of negative emotions (Gąsior, 2012), which is reflected in the author's research. Nonetheless, it is also emphasised that the father's addiction may have a negative influence on the mother's well-being, her emotional accessibility for children and bigger difficulties in the relationship with them. One can assume that in the present study it can be expressed in the assessment of the mother as more rejecting and emotionally distant, although the above dependence concerns only alcohol-dependent females with a family history of alcohol addiction (who in other dimensions assess the mother's attitude similarly to females without addiction in the family history). It would mean - similarly to Gąsior's ACA typology (2012) (ACA from the families of low dysfunctionality and differentiated intensification of dysfunctionalities) - that the image of the mother among the alcohol-dependent individuals with a family history of alcohol addiction (in the present studies mostly the addiction of the father) appears to be relatively positive, next to a rather negative image of the father. However, there are also studies in which it is highlighted that the influence of the memories regarding the parenting style acquired by parents, especially maternal, plays a slightly smaller role among the addicted individuals than among individuals with no addiction (De Jong and Jacobs, 2010). To sum up: it seems that the obtained results reflect the emphasised in the literature view that the perception of the parents by the individuals with alcohol dependence is ambiguous, probably conditioned by many difficult to define factors and individual experiences in relationship with the parents (Gąsior, 2012; Grzegorzewska, 2013). Nevertheless conducting studies on the perception of the parent among the i hamującego autonomię. Jako że uzależnienie w rodzinie dotyczyło w niniejszych badaniach głównie ojca, wydaje się, iż picie przez niego alkoholu znajduje wyraz w ocenach dorosłych dzieci, choć - co ciekawe - są to oceny różniące się w zależności od płci. Jak wskazują dane z literatury, uzależnienie ojca wiąże się z mniejszą wrażliwością rodzicielską, mniejszym zaangażowaniem czy wyższym poziomem negatywnych emocji (Gąsior, 2012), co odzwierciedlają wyniki badań własnych. Niemniej podkreśla się również, że uzależnienie ojca może mieć negatywny wpływ na samopoczucie matki, jej mniejszą dostępność emocjonalną dla dzieci i większe trudności w relacjach z nimi. Można uznać, że w prezentowanych badaniach wyraża się to w ocenie matki jako bardziej odrzucającej i chłodnej emocjonalnie, jednak powyższa zależność dotyczy tylko kobiet uzależnionych $\mathrm{z}$ historią uzależnienia w rodzinie (które w pozostałych wymiarach oceniają postawę matki porównywalnie do kobiet bez rodzinnej historii uzależnienia). Oznaczałoby to, że - podobnie jak w przedstawionej przez Gąsiora (2012) typologii dda (dda z rodzin o niskiej dysfunkcjonalności i o zróżnicowanym nasileniu dysfunkcjonalności) obraz matki u osób uzależnionych od alkoholu z historią uzależnienia w rodzinie ( $w$ niniejszych badaniach w głównej mierze było to uzależnienie ojca) wydaje się względnie pozytywny, przy raczej negatywnym obrazie ojca. Są jednak także badania, w których podkreśla się, że wpływ wspomnień rodzicielskiego stylu wychowania, zwłaszcza matczynego, odgrywa u osób uzależnionych nieco mniejszą rolę niż u osób bez uzależnienia (De Jong i Jacobs, 2010).

Podsumowując: jak się wydaje, uzyskane wyniki odzwierciedlają podkreślany w literaturze pogląd, iż percepcja rodziców przez osoby uzależnione od alkoholu jest niejednoznaczna, prawdopodobnie zależna od wielu trudnych do zdefiniowania czynników oraz indywidualnych doświadczeń w relacji z rodzicami (Gąsior, 2012; Grzegorzewska, 2013). Niemniej badanie percepcji rodzica wśród osób uzależnionych od alkoholu ma znaczenie praktyczne, zwłaszcza w obszarze projektowania oddziaływań terapeutycznych w trakcie pogłębionej psychoterapii osób uzależnionych. W przyszłych badaniach ciekawe byłyby zarówno połączenie retrospektywnej oceny rodziców ze stylami przywiązania osób uzależnionych, jak i próba uchwycenia transmisji rodzinnej funkcjonowania rodzicielskiego przez porównanie oceny własnych rodziców z oceną siebie jako rodzica. Zastosowanie planu podłużnego dla obserwacji ewentualnych zmian w ocenie rodzica w toku terapii (zwłaszcza pogłębionej) również mogłoby dostarczyć istotnych informacji, wzbogacających obraz kliniczny osób uzależnionych od alkoholu.

Za poważne ograniczenie prezentowanych badań trzeba uznać niemożność, ze względu na różnice w liczebności podgrup, postawienia bardziej szczegółowych hipotez dotyczących retrospektywnej oceny rodzica z uwzględnieniem płci rodzica uzależnionego. Do przyszłych badań należy zebrać wystarczającą liczbę osób z historią uzależnienia matki, ojca i obojga rodziców; wskazane byłoby też porównanie 
alcohol-dependent individuals has practical implications, especially in the area of planning therapeutic interventions during intense psychotherapy for the addicted. In the future studies it would be interesting to connect the retrospectively assessed parental attitudes with the attachment styles of the addicted individuals as well as an attempt to detect a family transmission of parental functioning by comparing the assessment of one's own parent with the assessment of themselves as parents. The use of a longitudinal plan for observing any possible changes in the assessment of the parent during therapy (especially deepened) could also provide significant information, enriching clinical image of the alcoholdependent individuals.

The impossibility, due to the differences in the number of respondents in the subgroups, to pose more detailed hypotheses concerning the retrospective assessment of the parent taking into consideration the sex of the addicted parent, should be considered as a serious limitation. As for the future research, it is advised to collect a sufficient number of people with the family history of the addicted mother, father and both parents; it would be also advisable to compare the above groups with one another. Purposive sampling of the respondents among the patients of state addiction centres, who undertake psychotherapy, makes the sampling specific, which does not allow to generalise the results for the whole group of the addicted individuals. What is more, it should be also taken into consideration that the alcoholdependent individuals' perception of the childhood experiences connected with the parental care may be distorted by addiction mechanisms or also by one's own experiences of being a parent. Finally, also the number of females in both studies seems to be a significant issue. The proportion of alcohol-dependent females to alcohol-dependent males reflects the proportion of females to males undertaking addiction treatment (1:4; cf. Gąsior, 2006), although the small number of participating females should be treated as studies' limitation.

\section{CONCLUSIONS}

The retrospectively assessed parental attitudes performed by the alcohol-dependent individuals, also by those who have addicted parents, seems to be ambiguous and complex. The people with alcohol dependence tended to assess the attitude of the father more unfavourably than the non-dependent individuals. Having an alcohol-dependent parent among the individuals addicted to alcohol diversifies mainly the retrospective assessment of the father.

\section{Conflict of interest}

The author declares a lack of conflict of interest. powyższych grup między sobą. Celowy dobór badanych spośród pacjentów państwowych placówek odwykowych, którzy podejmują psychoterapię, stanowi o pewnej specyficzności próby, co nie pozwala na generalizację wyników na całą grupę osób uzależnionych od alkoholu. Ponadto trzeba uwzględnić fakt, że postrzeganie przez osoby uzależnione doświadczeń z dzieciństwa związanych z opieką rodzicielską może być zniekształcone przez mechanizmy uzależnienia, a także przez własne doświadczenie bycia rodzicem. Istotną kwestią jest wreszcie liczba kobiet w obu badaniach. Proporcja liczby uzależnionych kobiet do uzależnionych mężczyzn odzwierciedla proporcję kobiet do mężczyzn podejmujących leczenie odwykowe (1:4; por. Gąsior, 2006), jednak małą liczebność grupy kobiet uznać należy za ograniczenie badań.

\section{WNIOSKI}

Retrospektywna ocena postaw matki i ojca dokonywana przez osoby uzależnione od alkoholu, także te mające uzależnionych rodziców, wydaje się niejednoznaczna i złożona. Osoby uzależnione od alkoholu bardziej niekorzystnie niż nieuzależnione oceniają postawę ojca. Posiadanie przez osoby uzależnione od alkoholu uzależnionego rodzica różnicuje głównie retrospektywną ocenę ojca.

\section{Konflikt interesów}

Autorka deklaruje brak konfliktu interesów.

\section{References / Piśmiennictwo}

Allen JG, Fonagy P, Bateman AW: Mentalizowanie w praktyce klinicznej. Wydawnictwo Uniwersytetu Jagiellońskiego, Kraków 2014.

Backer-Fulghum LM, Patock-Peckham JA, King KM et al.: The stressresponse dampening hypothesis: how self-esteem and stress act as mechanisms between negative parental bonds and alcohol-related problems in emerging adulthood. Addict Behav 2012; 37: 477-484.

Bomba J: Przywiązanie a rozwój mózgu. In: Józefik B, Iniewicz G (eds.): Koncepcja przywiązania. Od teorii do praktyki klinicznej. Wydawnictwo Uniwersytetu Jagiellońskiego, Kraków 2008: 25-33.

Bowlby J: Przywiązanie. Wydawnictwo Naukowe PWN, Warszawa 2007.

Branstetter SA, Furman W, Cottrell L: The influence of representations of attachment, maternal-adolescent relationship quality, and maternal monitoring on adolescent substance use: a 2-year longitudinal examination. Child Dev 2009; 80: 1448-1462.

Cierpiałkowska L, Grzegorzewska I: Dzieci alkoholików w perspektywie rozwojowej i klinicznej. Wydawnictwo Naukowe UAM, Poznań 2016.

De Jong CAJ, Jacobs P: Interpersonal self-perception and memories on parental rearing in alcohol dependent patients and outpatient controls. The Open Addiction Journal 2010; 3: 43-49.

De Rick A, Vanheule S: The relationship between perceived parenting, adult attachment style and alexithymia in alcoholic inpatients. Addict Behav 2006; 31: 1265-1270.

Dragan M: Doświadczenia traumatyczne a uzależnienie od alkoholu. Wydawnictwa Uniwersytetu Warszawskiego, Warszawa 2008.

Fudała J: Rozpoznawanie osób pijących alkohol w sposób ryzykowny i szkodliwy. In: Bętkowska-Korpała B (ed.): Uzależnienia w praktyce klinicznej. Zagadnienia diagnostyczne. Państwowa Agencja Rozwiązywania Problemów Alkoholowych, Warszawa 2009: 37-58. 
Gąsior K: Czynniki zagrażające i chroniące związane ze stresem pourazowym u Dorosłych Dzieci Alkoholików. In: Widera-Wysoczańska A, Kuczyńska A (eds.): Interpersonalna trauma. Mechanizmy i konsekwencje. Difin, Warszawa 2011: 238-255.

Gąsior K: Funkcjonowanie noo-psychospołeczne i problemy psychiczne dorosłych dzieci alkoholików. Difin, Warszawa 2012.

Gąsior K: Typy alkoholizmu kobiet. Badania, interpretacja psychologiczna, psychoterapia. Kaligraf, Kielce 2006.

Golińska L: Niektóre aspekty funkcjonowania intrapsychicznego i interpersonalnego dorosłych dzieci alkoholików. In: Gąsior K, Chodkiewicz J (eds.): Leczenie alkoholików i członków ich rodzin. Perspektywa badawcza i praktyczna. Jedność, Kielce 2010: 264-278.

Grzegorzewska I: Odporność psychiczna dzieci alkoholików. Wydawnictwo Naukowe Scholar, Warszawa 2013.

Grzegorzewska I: Podatność na traumę czy budowanie odporności? Dziecko w rodzinie z problemem alkoholowym. In: Widera-Wysoczańska A, Kuczyńska A (eds.): Interpersonalna trauma. Mechanizmy i konsekwencje. Difin, Warszawa 2011: 225-238.

Habib C, Santoro J, Kremer P et al.: The importance of family management, closeness with father and family structure in early adolescent alcohol use. Addiction 2010; 105: 1750-1758.

Kelley ML, Braitman A, Henson JM et al.: Relationships among depressive mood symptoms and parent and peer relations in collegiate children of alcoholics. Am J Orthopsychiatry 2010; 80: 204-212.

Kelley ML, French A, Schroeder V et al.: Mother-daughter and fatherdaughter attachment of college student ACOAs. Subst Use Misuse 2008; 43: 1562-1570.

Kelley ML, Nair V, Rawlings T et al.: Retrospective reports of parenting received in their families of origin: relationships to adult attachment in adult children of alcoholics. Addict Behav 2005; 30: 1479-1495.

Kroll B: Living with an elephant: growing up with parental substance misuse. Child Fam Soc Work 2004; 9: 129-140.

McKay MT, Sumnall H, Goudie AJ et al.: What differentiates adolescent problematic drinkers from their peers? Results from a crosssectional study in Northern Irish school children. Drugs (Abingdon Engl) 2011; 18: 187-199.

Najavits LM: Poszukiwanie bezpieczeństwa: terapia PTSD i nadużywania substancji psychoaktywnych. Wydawnictwo Uniwersytetu Jagiellońskiego, Kraków 2010.

Patock-Peckham JA, Morgan-Lopez AA: College drinking behaviors: mediational links between parenting styles, parental bonds, depression, and alcohol problems. Psychol Addict Behav 2007; 21: 297-306.

Patock-Peckham JA, Morgan-Lopez AA: Direct and mediational links between parental bonds and neglect, antisocial personality, reasons for drinking, alcohol use, and alcohol problems. J Stud Alcohol Drugs 2010; 71: 95-104.
Patock-Peckham JA, Morgan-Lopez AA: Mediational links among parenting styles, perceptions of parental confidence, self-esteem, and depression on alcohol-related problems in emerging adulthood. J Stud Alcohol Drugs 2009; 70: 215-226.

Patock-Peckham JA, Cheong J, Balhorn ME et al.: A social learning perspective: a model of parenting styles, self-regulation, perceived drinking control, and alcohol use and problems. Alcohol Clin Exp Res 2001; 25: 1284-1292.

Plopa M: Psychologia rodziny: teoria i badania. Oficyna Wydawnicza „Impuls”, Kraków 2007.

Plopa M: Więzi w małżeństwie i rodzinie. Metody badań. Oficyna Wydawnicza „Impuls”, Kraków 2005.

Schore AN: Zaburzenie regulacji prawej półkuli mózgowej: podstawowy mechanizm traumatycznego przywiązania i psychopatogenezy stresowego zaburzenia pourazowego. In: Murawiec S, Żechowski C (eds.): Od neurobiologii do psychoterapii. Instytut Psychiatrii i Neurologii, Warszawa 2009: 71-121.

Senator D: Teoria więzi Johna Bowlby'ego. In: Tryjarska B (ed.): Bliskość w rodzinie. Więzi w dzieciństwie a zaburzenia w dorosłości. Wydawnictwo Naukowe Scholar, Warszawa 2012: 17-39.

Spooner C: Causes and correlates of adolescent drug abuse and implications for treatment. Drug Alcohol Rev 1999; 18: 453-475.

Świtała J: Teoria relacji z obiektem O. F. Kernberga - prezentacja podstawowych założeń. In: Cierpiałkowska L, Gościniak J (eds.): Współczesna psychoanaliza. Teorie relacji z obiektem. Wydawnictwo Fundacji Humaniora, Poznań 2002: 67-94.

Tryjarska B: Style przywiązania partnerów a tworzenie bliskich związków w dorosłości. In: B. Tryjarska (ed.): Bliskość w rodzinie. Więzi w dzieciństwie a zaburzenia w dorosłości. Wydawnictwo Naukowe Scholar, Warszawa 2012: 185-217.

Visser L, de Winter AF, Reijneveld SA: The parent-child relationship and adolescent alcohol use: a systematic review of longitudinal studies. BMC Public Health 2012; 12: 886.

Wallin DJ: Przywiązanie w psychoterapii. Wydawnictwo Uniwersytetu Jagiellońskiego, Kraków 2011.

Wojciszke B: Postawy i ich zmiana. In: Strelau J (ed.): Psychologia. Podręcznik akademicki. Tom III: Jednostka w społeczeństwie i elementy psychologii stosowanej. Gdańskie Wydawnictwo Psychologiczne, Sopot 2007: 79-106.

Ziemska M: Postawy rodzicielskie. Wiedza Powszechna, Warszawa 1969.

Żechowski C, Namysłowska I: Teoria przywiązania a rozwój zaburzeń psychicznych. In: Józefik B, Iniewicz G (eds.): Koncepcja przywiązania. Od teorii do praktyki klinicznej. Wydawnictwo Uniwersytetu Jagiellońskiego, Kraków 2008: 53-74. 